Modern Asian Studies 51, 4 (2017) pp. 879-918. (C) Cambridge University Press 2017 doi:10.1017/Soo26749X15000402 First published online 22 June 2017

\title{
Cultivating Subjects: Opium and rule in post-colonial Vietnam*
}

\author{
CHRISTIAN G. LENTZ \\ Department of Geography, University of North Carolina at Chapel Hill, \\ Chapel Hill, North Carolina, United States of America \\ Email: cclentz@email.unc.edu
}

\begin{abstract}
Swidden cultivators in the Southeast Asian highlands may work far from lowland centres, but certain crops attract powerful interests. During the First Indochina War (1946-54), French and Vietnamese political actors climbed the hills in pursuit of the Black River region's opium production and trade. Even after combat formally ended, opium contests continued into an independent Vietnam, intersecting with larger struggles over ethnic difference, state resource claims, and market organization. Using upland cultivators to examine post-colonial statemaking, this article tells a new story about opium's tangled relationship with socialist rule in Vietnam. Drawing on French and Vietnamese archival records, it traces the operation of successive opium regimes through war and into restive peace. Based on evidence of opium tax and purchase operations conducted by the Democratic Republic of Vietnam (DRV) from $195^{1}$ to 1960 , it argues that regulating the commodity sensitized cultivators to their long, fraught relations with state power. Far from passive, cultivating subjects animated revolutionary ideals, engaged smuggling networks, negotiated resource rights, and mounted an oppositional social movement. Peaking in 1957, the movement and subsequent crackdown illustrate tensions embedded in post-colonial relations of exchange and rule.
\end{abstract}

* This article benefited from presentations at the Conference on Property and Citizenship in Developing Countries in Copenhagen, the Center for Southeast Asian Studies at University of Wisconsin-Madison, and the Association of Asian Studies meeting in Philadelphia. Thanks to Hue-Tam Ho Tai, Eric Tagliacozzo, Gaby Valdivia, Townsend Middleton, Elizabeth Havice, Adriane Lentz-Smith, and anonymous reviewers of Modern Asian Studies for comments on previous drafts. The University of North Carolina at Chapel Hill's Center for Global Initiatives and Carolina Asia Center provided generous research funding. I am grateful to the Skagen School, especially Michael Eilenberg and Christian Lund, for collegial writing support. 


\section{Introduction}

This article explores the world and subjects opium made in $195^{\text {os-era }}$ Vietnam. In the mountainous Black River region bordering China and Laos, mid-twentieth-century opium contests intersected with larger struggles over ethnic difference, resource claims, and market organization (see Figure 1). ${ }^{1}$ Using upland cultivators to examine post-colonial statemaking, 'Cultivating Subjects' argues that opium production and taxation in the post-colony sensitized cultivators to their long, fraught relations with state power. ${ }^{2}$

Swidden cultivators in the South East Asian highlands may work far from lowland centres, but certain crops attract powerful interest. During the embattled transition from French to Vietnamese rule, state and military actors climbed the hills to regulate Black River opium cultivation according to respective opium 'regimes'-régie in Indochina and chếđộ in the Democratic Republic of Vietnam (DRV)in which each state developed policies and practices to control use, production, and exchange within its domain. ${ }^{3}$ Opium was and remains a compound with many uses and meanings as well as a global commodity enmeshed in complex political-economic relations. In fact, smallholding poppy cultivators in the adjacent 'Golden Triangle' region of Laos, Myanmar (Burma), and Thailand have long valued opium for both its medicinal properties and high market price. ${ }^{4}$ With whom they exchange their crop, and on what terms, depends not only on market demand, but also on opium regimes imbued with ideology and backed by force. When Indochina and Democratic Republic of Vietnam levied taxes on smallholder production, they generated much

\footnotetext{
${ }^{1}$ On the region's longer history, see P. Le Failler, La Rivière Noire: L'intégration d'une marche frontière au Vietnam, CNRS Éditions, Paris, 2014.

${ }^{2}$ Not definitive, the 'post' in post-colonial was and is a work in progress. A. Mbembe, 'Provisional notes on the postcolony', Africa: Journal of the International African Institute, vol. 62, no. 1, 1992, pp. 3-37; P. Pelley, Postcolonial Vietnam: New Histories of the National Past, Duke University Press, Durham, 2002.

${ }^{3}$ T. Brook and B. Wakabayashi, 'Introduction: opium's history in China', in Opium Regimes: China, Britain, and Japan, I839-1952, T. Brook and B. Wakabayashi (eds), University of California Press, Berkeley, 2000, pp. 1-27.

${ }^{4} \mathrm{~J}$. Westermayer, Poppies, Pipes, and People: Opium and Its Use in Laos, University of California Press, Berkeley, 1982; T. Fuller, 'Myanmar returns to what sells: heroin', The New York Times, 3 January 2015.
} 


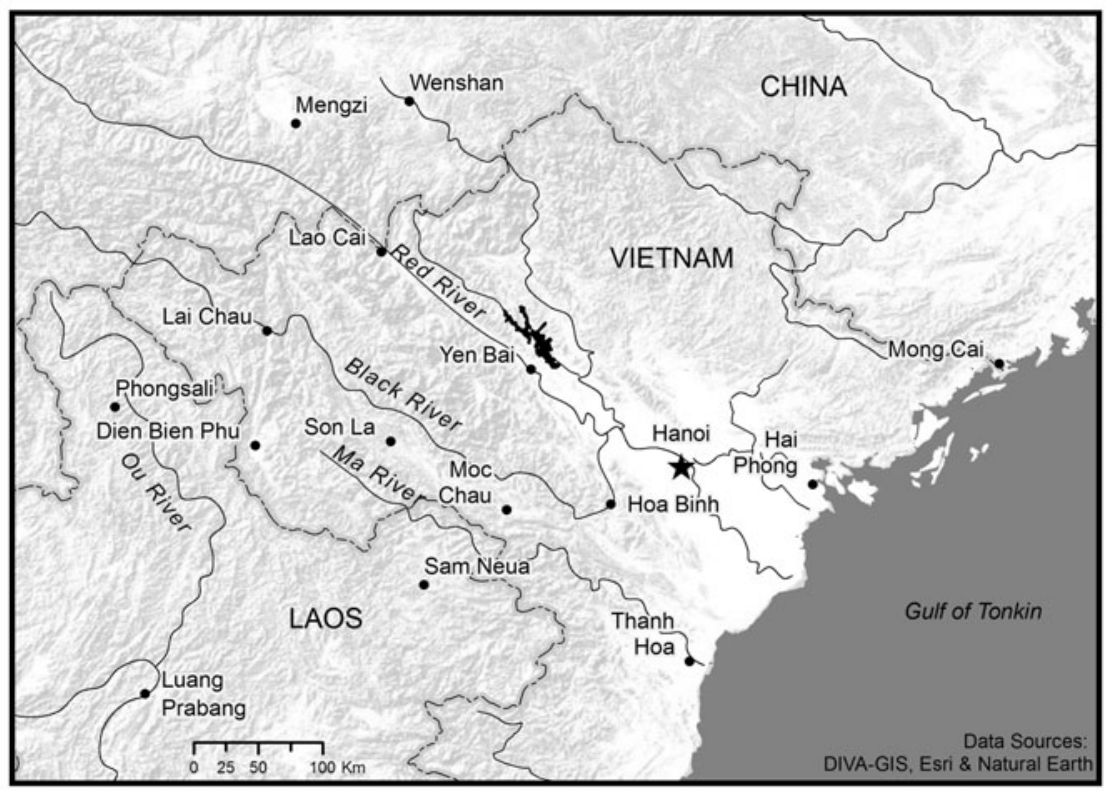

Figure 1. The Black River region, administered under the Tonkin Protectorate during French rule of Indochina.

Source: Map by Amanda Henley.

more than revenue. They produced relations of ruler and subject as well as ideas of state itself and its legitimate power. ${ }^{5}$

Based on analysis of records from Vietnam's National Archives and France's Military and Overseas Archives, this study tells a new story about opium's tangled relationship with post-colonial socialist rule in Vietnam. ${ }^{6}$ Historians of French Indochina have demonstrated how, in the first half of the twentieth century, the colonial opium monopoly functioned as a significant revenue source in an oppressive tax system. ${ }^{7}$ Although nationalist leaders condemned the monopoly,

${ }^{5}$ P. Abrams, 'Notes on the difficulty of studying the state', Journal of Historical Sociology, vol. 1, no. 1, 1988, pp. 58-89; T. Sikor and C. Lund, 'Access and property: a question of power and authority', Development and Change, vol. 40, no. 1, 2009, pp. 122; C. C. Lentz, 'The king yields to the village? A micropolitics of statemaking in Northwest Vietnam', Political Geography, vol. 39, March 2014, pp. 1-10.

${ }^{6}$ Trung tâm Lưu trũ̃ Quốc gia Việt Nam 1 and 3, Hanoi (abbreviated as NAVC 1 and 3); Archives Nationale d'Outre Mer, Aix en Provence (abbreviated as AOM); Service Historique de la Défense, Paris (abbreviated as SHD).

${ }^{7}$ P. Brocheux and D. Hémery, Indochina: An Ambiguous Colonization, I858-1954, University of California Press, Berkeley, 2009; C. Descours-Gatins, Quand Opium 
studies of the Vietnamese revolution-from the Second World War, through the First Indochina War (1946-54), until French defeat in 1954-reveal that opium revenue likewise helped the Viet Minh Front and early Democratic Republic of Vietnam build an army and finance a government. ${ }^{8}$ Scholarship on opium politics highlights the trade in northern Vietnam until 1954, discusses heroin's production in the Golden Triangle and use in southern Vietnam during the Second Indochina War ( $1965-75)$, and analyses suppression policies in united Vietnam from the early 1990 . $^{9}$ In spite of these rich insights, distinguished historian David Marr recently noted that 'few statistics are available on DRV monopoly operations'. ${ }^{10}$ Taking up his challenge, this article dates the Democratic Republic of Vietnam monopoly's formal establishment to $195^{1}$, discusses how policy shifted from what I call the 'revolutionary exchange' during war to outright taxation in $195^{6}$, and details north-west Vietnam's official opium receipts from 1953 until 1960.

Rather than plugging a gap on opium's history in Vietnam per se, this article emphasizes the unstable subject and exchange relations that sprung from regulating opium in a region undergoing violent, rapid social change. Known as the Sip Song Chau Thai (Twelve Thai Principalities) prior to French conquest in the late nineteenth century, the Black River region was a colonial backwater of Tonkin until the First Indochina War transformed the rugged frontier into a focal point of anti-colonial struggle. ${ }^{11}$ By defeating France at the 1954 Battle of

Finançait la Colonisation en Indochine, Harmattan, Paris, 1992; P. Le Failler, Monopole et Prohibition de l'Opium en Indochine, Harmattan, Paris, 2001.

${ }^{8}$ N. V. Long, Before the Revolution: The Vietnamese Peasants under the French, Columbia University Press, New York, 1991; J. T. McAlister, 'Mountain minorities and the Viet Minh: a key to the Indochina War', in Southeast Asian Tribes, Minorities, and Nations, Peter Kunstadter (ed.), Princeton University Press, Princeton, 1967, pp. 77 1-844; C. Goscha, Thailand and the Southeast Asian Networks of the Vietnamese Revolution, I885-1954, Curzon Press, Richmond, 1999.

${ }^{9}$ A. W. McCoy, The Politics of Heroin: CIA Complicity in the Global Heroin Trade, Lawrence Hill Books, New York, 1991; J. Windle, 'The suppression of illicit opium production in Viet Nam: an introductory narrative', Crime, Law, and Social Change, vol. 57,2012 , pp. $425^{-39}$.

${ }^{10}$ D. G. Marr, Vietnam: State, War, and Revolution (1945-1946), University of California Press, Berkeley, 2013, p. 361.

${ }^{11}$ T. Winichakul, Siam Mapped: A History of the Geobody of the Nation, University of Hawaii Press, Honolulu, 1995; B. Davis, 'Black flag rumors and the Black River Basin: powerbrokers and the state in the Tonkin-China Borderlands', Journal of Vietnamese Studies, vol. 6, no. 2, Summer 201 1, pp. 16-41; C. C. Lentz, 'Mobilization and state formation on a frontier of Vietnam', Journal of Peasant Studies, vol. 38, no. 3, July 2011 , pp. 559-86. 
Dien Bien Phu, the Democratic Republic of Vietnam secured national independence and territorial domination over one-third of its total area, recognized in 1955 as the Thái-Mèo Autonomous Zone. ${ }^{12}$ Now victorious, the nascent state also exerted monopoly control over the vast region's opium production and distribution. Indeed, Dien Bien Phu's markets served not only cultivators in the hills and officials in the valleys, but also as a hub in transnational trade, much of which was contraband. ${ }^{13}$ As under French rule, local participation in illicit markets subverted the Democratic Republic of Vietnam opium 'monopoly'. Further, Democratic Republic of Vietnam taxation and compulsory purchase raised the spectre of colonialism. As a result, official opium receipts function not as neutral measures of production, but rather as an index of cultivator grievance with the prevailing opium regime. Smuggling both diverted a source of official revenue and undermined state claims to legitimate control of resource flows. ${ }^{14}$

This discussion of opium's role in the emergence of nation-state rule, namely the period when the Black River region became Vietnamese, engages two historical comparative literatures on Asia. ${ }^{15}$ First, it links historian Alfred McCoy's work on the global opium trade to renewed interest in mountainous frontiers led by political scientist James Scott. By tracing opium's financial path from colonial budget to counterinsurgency funding, McCoy explained how United States of America Cold War machinations helped make the Golden Triangle a leading narcotics producer. ${ }^{16}$ Yet his history does not account for the Democratic Republic of Vietnam opium regime and its political effects. Scott situates the Golden Triangle and the Black River region

${ }^{12}$ Of the Democratic Republic of Vietnam's total 158 ,ooo square kilometres $\left(\mathrm{km}^{2}\right)$ area, the Thái-Mèo Autonomous Zone (Khu tụ trị Thái-Mèo) measured 55 ,ooo km², approximately one-sixth of the united Socialist Republic of Vietnam. 'Tình hình khái quát về Khu tự trị dân tộc Thái-Mèo ở Tây-Bắc', May 1955, File No. 22/Ủy ban Hành chính Khu tự trị Tây Bắc (KTTTB) Record Group/NAVC 3; 'Báo cáo những nét khái quát về tình hình chúng của Khu tự trị Thái-Mèo’, 10 July 1960, 208/KTTTB/ NAVG 3 .

${ }^{13}$ McAlister, 'Mountain minorities', pp. 824-5.

${ }^{14}$ E. Tagliacozzo, Secret Trades, Porous Borders: Smuggling and States along a Southeast Asian Frontier, I865-1915, Yale University Press, New Haven, 2005; J. Ribot and N. Peluso, 'A theory of access', Rural Sociology, vol. 68, no. 2, 2003, pp. 153-81.

${ }^{15}$ C. C. Lentz, 'Making the Northwest Vietnamese', Journal of Vietnamese Studies, vol. 6, no. 2, Summer 2011 , pp. 68-105.

${ }^{16}$ McCoy, The Politics of Heroin; A. W. McCoy, 'The stimulus of prohibition: a critical history of the global narcotics trade', in Dangerous Harvest: Drug Plants and the Transformation of Indigenous Landscapes, M. Steinberg, J. Hobbs, and K. Matthewson (eds), Oxford University Press, Oxford, 2004, pp. 24-111. 
in the refugial space of 'Zomia' where culturally diverse highland peoples practise 'escape agriculture', including opium cultivation, in order to evade lowland civilizing projects. ${ }^{17}$ Yet his analysis ends in $195^{\circ}$ with the rise of nation-states and, further, overlooks the opium crop's two-sided appeal-that is, how it enabled smallholder autonomy and attracted powerful sovereign interests. ${ }^{18}$ By contrast, 'Cultivating Subjects' focuses squarely on the $195^{\text {os }}$ when lowland Kinh-Viet officers, cadres, and traders forged relations with diverse upstream inhabitants-Hmong (Mèo), Thái, Khmu (Xá), Lao, Dao (Mien), among others - at the dawn of the nation-state era. They also sought control over opium, provoking organized opposition that mixed millenarian social forms with a language of national rights and socialist equality.

Second, this discussion of Vietnam's post-colonial opium regime and its colonial precursor responds to a call for 'fresh', interdisciplinary approaches to studies of the nation-state in South East Asia. Just over 20 years ago, economic historian Howard Dick analysed colonial opium regimes in relation to modern state formation and questioned whether processes of colonization and decolonization really were antithetical. Echoing Benedict Anderson's observation that 'old' state forms could still dominate 'new' national societies, Dick challenged scholars to ask 'whether decolonization was such a watershed event after all'. ${ }^{19}$ Pointing to taxation and corvée labour, he argued for a study of statemaking that took full account of a state's coercive capacity to generate revenue. At first glance, evidence that the Democratic Republic of Vietnam built its opium regime on the French model

${ }^{17}$ J. C. Scott, The Art of Not Being Governed: An Anarchist History of Southeast Asia, Yale University Press, New Haven, 2009. See V. Lieberman, 'A zone of refuge in Southeast Asia? Reconceptualizing interior spaces', Journal of Global History, vol. 5, no. 2, July 2010 , pp. 333-46.

${ }^{18}$ Scott, The Art of Not Being Governed, pp. xii, 11 , Chapter 6.

${ }^{19}$ H. Dick, 'A fresh approach to Southeast Asian history', in The Rise and Fall of Revenue Farming: Business Elites and the Emergence of the Modern State in Southeast Asia, J. Butcher and H. Dick (eds), St Martin's Press, New York, 1993, pp. 3-18. Dick drew on a classic exchange regarding Indonesia's political development between Clifford Geertz, who argued that traditional sentiments compromised modern civic identities, and Benedict Anderson, who responded that the Indonesian state's colonial form continued after independence to constrain national aspirations. C. Geertz, 'The integrative revolution: primordial sentiments and civil politics in the new states', in Old Societies and New States: The Quest for Modernity in Asia and Africa, C. Geertz (ed.), Free Press of Glencoe, New York, 1963, pp. 105-57; B. Anderson, 'Old state, new society: Indonesia's new order in comparative historical perspective', Journal of Asian Studies, vol. 42, no. 3, May 1983, pp. 477-96. 
seems to confirm Dick's proposition of seamless continuity, 'namely that elements of the colonial state have been extremely durable, being incorporated with apparent ease into the succeeding nation-state'. ${ }^{20}$ Yet, while the cash-strapped Democratic Republic of Vietnam drew on opium revenue, using old institutional forms to do so in Vietnam's fissiparous national society was never easy. When nationalist leaders including Ho Chi Minh denounced the French for pushing opium on the Vietnamese and taxing the peasantry to death, they complicated Democratic Republic of Vietnam efforts to legitimize taxing and purchasing opium among cultivators and cadres alike. ${ }^{21}$ As a result, the post-colonial opium regime split state itself in three ways: arraying central ministries against one another, exposing tensions between central planning and regional autonomy, and cloaking official opium deals in secrecy and euphemism. Moreover, it revealed old social cleavages dressed in new guise: although opposition to Democratic Republic of Vietnam taxation rallied Hmong cultivators similar to the earlier Pa Chai Rebellion (1918-21), a 1956-57 messianic movement appealed to a broader constituency versed in ideas and practices learned through processes of national state formation. ${ }^{22}$

The main body of this article is divided into four parts. Beginning in the late colonial period, the first part introduces Indochina's institutional template and analyses foundational relations between officials, militants, and cultivators. The second discusses the establishment of the Democratic Republic of Vietnam opium regime and traces its operation during the First Indochina War. Picking up from independence, the third section analyses a policy shift from revolutionary exchange to taxation and compulsory purchase. The final part views the rise of a social movement in light of tensions embedded in broader relations of Democratic Republic of Vietnam exchange and rule. A conclusion situates the transformed Black River region in South East Asia's montane frontier, discusses Vietnam's decolonization from a regional and comparative perspective, and comments on opium's legacy in the archives and on the ground.

${ }^{20}$ Dick, 'A fresh approach', pp. 4-5.

${ }^{21}$ See his 1945 Declaration of Independence, discussed below.

${ }^{22}$ The movement predates the 1959 advent of a Hmong alphabet in Laos and ensuing messianic movement. See W. A. Smalley, C. K. Vang, and G. Y. Yang, Mother of Writing: The Origin and Development of a Hmong Messianic Script, University of Chicago Press, Chicago, 199o; N. Tapp, J. Michaud, C. Culas, and G. Y. Lee (eds), Hmong/Miao in Asia, Silkworm Books, Chiang Mai, 2004. 


\section{Late colonial contradictions}

Locating the roots of enduring cleavages in society, state, and economy in the colonial era, this article sets aside easy claims of rupture to trace the continuities embedded within even the most profound changes. Although Vietnam was and remains a multicultural society, French colonialism constructed ethnicity in terms of economic specialization, political privilege, and military advantage, bedevilling the project of national unity. ${ }^{23}$ Colonial violence and counterinsurgency warfare entrenched ethnic differences among opium cultivators, producing political blocs that challenged any state effort to collect revenue. ${ }^{24}$ Their legacy bled into post-colonial debates over the legitimacy of tax claims and the duties of citizens, prompting policy negotiations within the Democratic Republic of Vietnam and contributing to messianic counter-movements. In a fractured society impoverished by colonial capitalism, socialist visions of fairness, development, and equality won broad appeal. Yet, implementing a planned economy after devastating wars not only caused contradictions between theory and practice, but also amplified already complex relations between official and unofficial economies.

Indochina's monopolies generated state revenue and relations of colonial domination. In an effort to shore up the French colony's finances, late nineteenth-century reforms instituted state controls (régies) over opium, salt, and alcohol. From 1902 until the end of colonial rule in 1954, according to one reckoning, the combined monopolies never accounted for less than half of Indochina's general budgetary revenue. ${ }^{25}$ While regulations on salt and alcohol affected a larger share of the population, government control of opium's purchase, production, and retail was the most lucrative. By importing raw opium from India and Yunnan, manufacturing a smokable form in Saigon, and running thousands of dens and shops, Indochina's opium operation from 1899 to 1922 contributed, on average, 20 per cent

${ }^{23}$ H. K. Khanh, Vietnamese Communism, I92 5- I945, Cornell University Press, Ithaca, 1982, pp. 275-80; O. Salemink, The Ethnography of Vietnam's Central Highlanders: A Historical Contextualization, University of Hawai'i Press, Honolulu, 2003, pp. 62-4.

${ }^{24}$ H. Jonsson, 'War's ontogeny: militias and ethnic boundaries in Laos and exile', Southeast Asian Studies, vol. 47, no. 2, September 2009, pp. $125^{-49}$.

${ }^{25}$ H. Nankoe, J.-C. Gerlus, and M. Murray, 'The origins of the opium trade and the opium regie in colonial Indochina', in The Rise and Fall of Revenue Farming, Butcher and Dick (eds), p. 183 . 
towards the general budget. ${ }^{26}$ Even after trade disruptions owing to the Great Depression and a growing international prohibition movement, opium nonetheless accounted for 15 per cent of total colonial tax revenues in 1938-the highest proportion in South East Asia. ${ }^{27}$ Yet duties on opium, alcohol, and salt, derided colloquially as the three 'beasts of burden' (bêtes de somme), added to an already heavy tax load. On top of direct taxes (on individuals, income, and property), state monopolies levied an indirect tax managed by the Department of Customs and Excises (Douanes et Régies). At one point, the largest single branch of the Indochinese State, Customs and Excises' enforcement powers made it what historian Gerard Sasges calls 'the primary means by which the central state asserted rule over its subjects'. ${ }^{28}$ Its pursuit of revenue enacted colonial domination among ordinary Vietnamese subjects, associating state monopoly control with unjust exploitation.

Japan's occupation of Indochina during the Second World War provoked a crisis for French rule and its opium monopoly and, in so doing, opened opportunities for Vietnamese nationalists. After France's defeat in Europe, pro-Vichy colonial officials collaborated with the Japanese military to maintain Indochina's administrative and political status quo. ${ }^{29}$ An allied embargo on shipping to Indochina severed opium imports from overseas and caused local prices to skyrocket. Vichy administrators scrambled to secure a new opium supply, without which the colony faced a major budgetary shortfall. ${ }^{30}$ Their decision to cultivate sources within Indochina's colonial domain set the stage for enduring battles over opium's local production and trade. Faced with a fascist-imperialist alliance, Ho Chi Minh and other Vietnamese anti-colonial leaders regrouped along Tonkin's Sino-Viet border, founded the Viet Minh Front in 1941, and called for a national liberation revolution. Working from the Việt Bắc base area, Viet Minh cadres prepared for protracted guerrilla war by adapting to a context

\footnotetext{
${ }^{26}$ Brocheux and Hémery, Indochina, p. 93; Descours-Gatin, Quand Opium Finançait la Colonisation, pp. 222-5.

${ }^{27}$ McCoy, The Politics of Heroin, p. 112.

${ }^{28}$ Gerard Sasges, 'State, enterprise, and the alcohol monopoly in colonial Vietnam', Journal of Southeast Asian Studies, vol. 43, no. 1, 2012, pp. 133-57.

${ }^{29}$ Brocheux and Hémery, Indochina, p. 341 .

${ }^{30}$ McCoy, The Politics of Heroin, p. 113 ; 'Rapports Economique pour le IVème Territoire Militaire', yrs 1933-40, File Nos 74203-74120, Résident Superieure au Tonkin Record Group, NAVG 1, Hanoi.
} 
where local opium cultivators were already immersed in transnational trade networks. ${ }^{31}$

Customs and Excises, now charged with developing local sources of opium, found favourable growing conditions but formidable competition for the post-harvest product. In the highlands of Tonkin and neighbouring Laos, Hmong and Dao peoples had long produced opium on a limited basis for personal consumption, medicine, and trade. ${ }^{32}$ Settled on high peaks and ridges above valley-dwelling neighbours, their swidden plots rose above the 1,ooo-metre minimum for cultivating poppies (Papaver somniferum) in tropical latitudes. ${ }^{33}$ Counting on these smallholders to make up for lost imports, Customs and Excises launched an 'opium purchasing campaign' in 1940. ${ }^{34}$ Their efforts contributed to a broader expansion and intensification of opium production across the mountains of Laos and northern Tonkin (see Figure 2). Having already compromised the colonial monopoly, an illicit trade now capitalized on increased production associated with the campaign. ${ }^{35}$ Between 1940 and 1943, Customs and Excises receipts leapt ten-fold (from 4.3 tons to 40.3 ) in Laos but merely doubled (from 3 tons to 7.8) in Tonkin. ${ }^{36}$ Indeed, the lion's share of estimated gross production (86 tons in Laos, $4^{2}$ in Tonkin) evaded the monopoly as 'contraband', leading a French official to worry that Indochina's 'opium production risks escaping us entirely'. ${ }^{37}$ Evidently, growth in opium production exceeded the colonial administration's ability to dictate its purchase. Now that the Viet Minh Front was in a position to buy up opium and fund anti-colonial activities, the unintended outcome threatened to undermine not only the colonial monopoly, but also the state it was meant to support.

The gap between estimated production and official opium receipts indicates how old grievances and shifting alliances structured opium's exchange. Along the Viet-Lao border with China, the transnational

${ }^{31}$ W. Duiker, The Communist Road to Power in Vietnam, Westview, Boulder, 1996, pp. $7 \mathrm{O}-5$.

${ }^{32}$ P. Gourou, Indochine Française: Le Tonkin, Macon, Paris, 1931, pp. 236-8.

${ }^{33}$ W. R. Geddes, 'Opium and the Miao: a study in ecological adjustment', Oceania, vol. 41, no. 1, September 1970, pp. 1-11; J. Westermayer, 'Opium and the people of Laos', in Dangerous Harvest, M. K. Steinberg et al. (eds), pp. $115^{-32 .}$

${ }^{34}$ J. Haelewyn, 'Circulaire', 13 January 1944, File No. 4179/Résident Superieure au Tonkin New (RST) Record Group/AOM.

${ }^{35}$ J. Dumarest, 'Les Monopoles de l'Opium et du Sel en Indochine', PhD thesis, Université de Lyon, 1938, pp. 132-46.

${ }^{36}$ All measures are in metric unless noted otherwise.

${ }^{37}$ Haelewyn, 'Circulaire', 13 January 1944, 41 79/RST/AOM. 


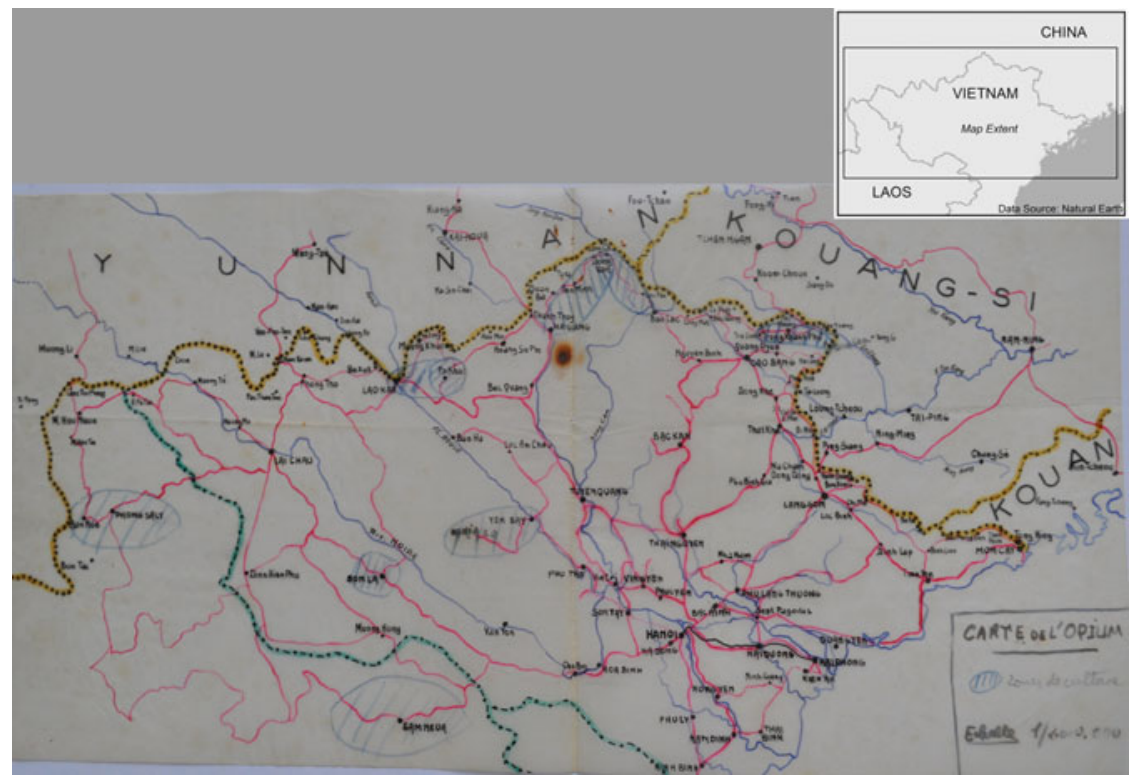

Figure 2. (Colour online) Handwritten 'Map of Opium' (1951?) featuring select cultivation areas (cross-hatched) in contested territory of Laos and Vietnam/Tonkin. Source: $2377 / 10 H /$ SHD.

trade in contraband opium built on cultivators' pre-existing discontent with the colonial monopoly. From 1918 to 1921 , for example, a charismatic Hmong leader called $\mathrm{Pa}$ Chai (aka, Pa Chay, Batchai, Bắt Chài) claimed supernatural powers and appealed to Hmong peoples chafing at French opium taxes levied by collaborating Thái and Lao officials. ${ }^{38}$ He led his followers into open rebellion, torched settlements around Dien Bien Phu, enslaved Khmu inhabitants, and terrorized Thái and Lao folk before pulling back to Laos, where a massive colonial force finally subdued his movement. ${ }^{39}$ In north-west Tonkin, Hmong mistrust of French-allied Thái leaders remained potent and grew with time. It was these political embers, and the underground networks they stoked, that the Viet Minh Front aimed to fan into a force for national liberation.

${ }^{38}$ G. G. Gunn, 'Shamans and rebels: the Batchai (Mèo) rebellion of northern Laos and north-west Vietnam (1918-1921)', Journal of the Siam Society, vol. 74, 1986, pp. $107-21$.

39 'Dien Bien Phu', 1933, File No. 1178, Indochina Series $10 H$ Record Group/SHD/Paris. 
After the Japanese surrender in August 1945 and the Democratic Republic of Vietnam declaration of independence a month later, France's project to re-secure north-west Tonkin rested on a savvy local partner and his opium connection. With French military backing, Đèo Văn Long claimed leadership of the so-called 'Thái Country' (Pays Thái) in 1946 and won title as president of the Thái Federation (194853). Following in the footsteps of his formidable father, Đèo Văn Trì (1848-19o8), who, in the late nineteenth century, had ushered the Sip Song Chau Thai into colonial Tonkin, the younger Đèo made himself indispensable to France's interest in frontier security. ${ }^{40}$ Renewing the colonial opium regime was central to their relationship-regardless of the monopoly's increasingly murky legal status. ${ }^{41}$ Although Indochina moved to restrict the public sale of opium in 1946, Đèo secured permission to structure an 'autonomous' budget based on opium and gaming revenues. ${ }^{42}$ As such, the Federation levied a dual tax on opium, first on the declared crop and then on undeclared proceeds spent in gambling dens, combining for over half its total budgetary income in $1948{ }^{43}$ Yet, similar to conditions in the Second World War, that year's official cut of five tons opium pushed an even larger share out of reach: French military intelligence estimated that cultivators declared only one-third of their harvest and smuggled the rest to China. ${ }^{44}$

The unstable mix of colonial re-conquest and national resistance placed opium at the forefront of increasingly violent and secretive contests over its production, trade, and taxation. Under the French Union's military umbrella, the Thái Federation commanded three Thái battalions to assist with regional 'pacification' and 'reoccupation'-euphemisms for bitter warfare against Hmong partisans and dissident Thái groups allied with the nascent

${ }^{40}$ P. Le Failler, 'The Đèo family of Lai Châu: traditional power and unconventional practices', Journal of Vietnamese Studies, vol. 6, no. 2, 201 1, pp. 42-67.

${ }^{41}$ McCoy reports Indochina abolished the opium monopoly in 1946, The Politics of Heroin, p. 131; Brocheux and Hémery describe its maintenance until $195^{\circ}$ when France ratified the United Nations' Drug Convention, Indochina, p. 95.

${ }^{42}$ P. Perrier, 'Regime de l'opium en Indochine', 5 April 1948, File No. 89/Conseiller Politique (Conspol)/Haut Commissariat de l'Indochine (HCI)/AOM; 'Projet de budget 1947 pur les Regions Thais', 3o October 1946, 21 4/Conspol/HCI/AOM.

${ }^{43}$ Lt Colonel Imfeld observed: 'The Thái budget, in receipts, was exclusively fournished by the Hmong who contributed half with raw opium and, the other half, indirectly, through the Chinese intermediaries who placed as bets the profits of their contraband opium', J. Jerusalemy, Monographie sur le Pays Thai, Typescript, 1953, p. 79.

${ }^{44}$ État Major, 2 eme Bureau, 'L'Opium au Tonkin', 1948, 2377/10H/SHD. 
Democratic Republic of Vietnam. ${ }^{45}$ Moreover, as the region's chief opium broker, Đèo Văn Long deployed his battalions to collect taxes and enforce the Federation monopoly. ${ }^{46}$ Ordered in $195^{1}$ to remove opium from the Federation budget, Đèo found new buyers who left few traces. The same year, a French report on opium production and commerce stated deceptively that the Department of Customs and Excise, long responsible for monopoly purchase, was now transferred to the 'Vietnamese government' and, hence, 'documentation on the subject is no longer in our hands'. ${ }^{47}$

In fact, as McCoy carefully documents, French military intelligence, in a secret programme known as 'Operation X', assumed control of the opium trade and redirected its proceeds to fund counterinsurgency operations. From $195^{1}$ to 1954 , Major Trinquier of the Mixed Airborne Commando Group coordinated opium purchases through the Thái Federation and flew loads to Saigon for marketing and distribution. He used the income to recruit and transform ethnically identified local inhabitants into maquis, self-sustaining teams that gathered intelligence, harassed the People's Army, and disrupted supply lines. According to Trinquier, working in secret avoided exposing the French military to what he called the 'international complications' such counterinsurgency tactics 'would surely evoke'. ${ }^{48}$ Sandwiched between two Hmong maquis—one to the west in Laos and another east of the Red River-Đèo Văn Long ran the Thái maquis in the Black River region of north-west Tonkin. ${ }^{49}$

Persistent contraband trade demonstrates, however, that allied Federation and French forces neither fully controlled opium's commodification nor determined its political effects. On the contrary, anti-colonial Vietnamese recognized grower dissatisfaction and used it to their advantage. On the Black River's southern bank, Democratic Republic of Vietnam officials reported how Hmong cultivators chafed at force used to purchase their crop at prices below market value. ${ }^{50}$

\footnotetext{
${ }^{45}$ Vaudrey, 'Le Pays Thai et l'Organisation Militaire de la ZANO en fin 1952', 23 December 1952, 2699/10H/SHD.

${ }^{46}$ McCoy, The Politics of Heroin, p. 142.

47 'Fiche sur la production et le commerce de l'opium dans le Nord Vietnam', 7 April 1951, 2377/10H/SHD.

${ }^{48}$ R. Trinquier, Modern Warfare: A French View of Counterinsurgency, Pall Mall, London, 1964 , p. 105 .

${ }_{49}$ McCoy, The Politics of Heroin, pp. 131-46, 289.

${ }^{50} \mathrm{~S}$. Văn Minh, 'Báo cáo ba tháng (tháng 7,8 , và 9 năm 1948)', no date, File No. 78, Phủ thủ Tướng (PTTg) Record Group, NAVC 3.
} 
Initially, according to a 1949 report, the Hmong were only 'lukewarm' (lìng chìng) regarding the revolutionary cause. But, once the French began 'killing' and 'arresting' Hmong people as well as burning and destroying their property, they began to 'hate' the French and turned favourably towards the resistance. ${ }^{51}$ Data from $195^{2}$ show that the Hmong population bore a heavy tax burden payable in opium: in addition to indirect taxes exacted through monopoly purchases, the Thái Federation levied direct taxes, including a head tax of five taels of opium ( 1 tael $=38$ grammes) per person and a 'swidden tax' averaging $5^{\text {o taels per household. }}{ }^{52}$

In fact, not all Hmong did grow opium even if they were subject to its tax. Discriminatory taxation, therefore, illustrates a longstanding French strategy of 'racial politics' (politique des races) that deliberately associated ethnic or racial difference with social function and position in Indochina's colonial hierarchy. ${ }^{53}$ The divisive tactics exempted Hmong and Dao peoples from corvée labour requirements, a common substitution for Tonkin's direct tax on individuals (head tax or capitation). ${ }^{54}$ Far from its traditional use as a palliative medicine, opium's role in a bitter conflict now inflamed inter-ethnic tensions, making it what two historians aptly call 'the nerve of the war'.55

Aware of these tactics, Viet Minh agents and Democratic Republic of Vietnam cadres appealed to grower discontent and capitalized on market conditions to create new political opportunities. Opium's high value to volume ratio and its fungibility on transnational trade networks provided them a polyvalent currency, namely as both a means of exchange and a source of surplus value. Local Chinese traders purchased opium for $800-1,5$ oo Indochinese piastres per kilogram

${ }^{51}$ L. Văn Mười, 'Báo cáo 3 tháng 1, 2, 3 năm 1949 của UBKCHC Liên tỉnh Sơn Lai', 5 April 1949, 187 /PTTg/NAVC 3.

${ }^{52} \mathrm{~N}$. Khang, 'Báo cáo công tác vùng mới giải phóng trong 2 tháng 10, 11/52', 29 December 1952, 1306/PTTg/NAVG 3. For more on the tael unit, see D. K. Basu, 'Chinese xenology and the opium war: reflections on sinocentrism', Journal of Asian Studies, vol. 73, no. 4, November 2014, p. 931.

${ }^{53}$ Comité Consultatif de la Défense des Colonies, 'Étude sur la création de troupes cambodgiennes et de troupes de frontière recrutées parmi les populations autochtones du HAUT TONKIN', 1910, File No. 2162, Gouvernement Général de l'Indochine Record Group, NAVC 1. See Le Failler, La Rivière Noire, p. 405.

${ }^{54}$ Brocheux and Hémery, Indochina, pp. 62-3.

${ }^{55}$ C. Descours-Gatin, Quand l'opium finançait la colonisation en Indochine, L'Harmattan, Paris, 1992, p. 267; Le Failler, La Rivière Noire, p. 448. 
and resold it in Hanoi for 13,00o-1 5, ooo piastres per kilogram. ${ }^{56}$ The roughly ten-fold price disparity drove a thriving underground market in which salt-bearing revolutionaries acted as middlemen between opium cultivators and weapons dealers. ${ }^{57}$

Anti-colonial activists cannily subverted colonial monopolies on salt and opium to procure weapons. With no local sources, salt purchased along the Gulf of Tonkin fetched enormous sums on the border with Yunnan, where it was known as 'white gold'. In the early 1940s, salt bought at 0.20 piastres per kilogram sold there for $5^{\circ}$ times its purchase price. ${ }^{58}$ A decade later, salt remained dear in the Thái Federation at 12-15 piastres per kilogram of rock salt and 20-25 piastres per kilograms of sea salt, in part because guerrilla disruption of road and river arteries restricted official supplies to air transport. ${ }^{59}$ Nationalist trade agents (affiliated first with the Viet Minh Front and then the Democratic Republic of Vietnam) brought these commodities into an equivalent relation, roughly 1 kilogram of opium $=1,000$ piastres $=100$ kilograms of salt. ${ }^{60}$ Opium in hand, agents tapped into transnational networks that stretched across South East Asia into China to collect surplus weapons from the latter's civil war. ${ }^{61}$ When the People's Republic of China followed their 1949 victory with an antidrug crusade, suppression of China's domestic production increased the value of Tonkin's crop and, consequently, the profitability of borderland smuggling. Proceeds from this trade, according to one estimate, were enough to arm all six divisions of the People's Army in $195^{2 .}{ }^{62}$

In sum, France's colonial opium regime suffered from two contradictions that crippled the Thái Federation and strengthened

${ }^{56}$ Jerusalemy, Monographie, p. 29.

${ }^{57}$ Surêté Federale du Tonkin, 'Bulletin des renseignements', 15 September 1949, 2377/10H/SHD; État Major 2ème Bureau, 'Bulletin des renseignements', 1 ère quinzaine July 1949, 2377/10H/SHD.

${ }^{58}$ D. Marr, Vietnam I945: The Quest for Power, University of California Press, Berkeley, 1995, p. 246.

${ }^{59}$ Jerusalemy, Monographie, p. 3o. Sea salt fetched higher prices because its iodine content treated goitre.

${ }^{60}$ J. T. McAlister, Viet Nam: The Origins of Revolution, Alfred A. Knopf, New York, 1969, p. 249; J. Picard, 'Vietminh economics', MA thesis, Cornell University, 2004, p. 53 .

${ }^{61}$ Surêté Federale du Tonkin, 'Bulletin de Renseignements', 15 September 1949, 2377/10H/SHD; État Major, 2ème Bureau, 'Bulletin de Renseignments', 13 August 1951, 2377/10H/SHD; Goscha, Thailand and the Southeast Asian Networks, p. 204.

${ }_{62}$ McAlister, 'Mountain minorities', p. 822. 
the nationalist opposition. First, incomplete 'legal' regulation of the opium crop contributed to 'illegal' smuggling, feeding an underground market endowed with alternative moral and political significance. By capitalizing on a lucrative arbitrage between borderland smugglers and dissatisfied growers, anti-colonial leaders armed themselves against France and the Thái Federation. Second, colonial force and heavy taxes exacerbated uneven exchange relations and contributed to a willingness among many Hmong cultivators to support the revolutionary cause. 'The Meo [Hmong] who are the large producers of opium,' wrote France's Thái Federation representative in 1951, 'feel a certain "squeeze" from the Tai [Thái] authorities who are their main outlet. ${ }^{93}$ Not a neutral observation, he pointed to the effects of associating ethnic difference with economic specialization and political privilege-what Vietnamese revolutionaries denounced as 'divide and rule' (chia để trị). Suspicious of the French-backed Thái bid towards regional supremacy, disgruntled opium cultivators joined the growing anti-colonial movement, which, thanks to revenue from their cash crop, now had guns.

\section{Anti-colonial warfare and the revolutionary exchange}

While Operation X transformed France's share of the opium economy into an instrument of counterinsurgency, Democratic Republic of Vietnam officials formulated a legal framework for taxing and purchasing opium directly from producers. In $195^{1}$, the prime minister's secretariat issued Temporary Regulations on Opium that considered opium a 'specialty manufacture' and articulated key features of the Democratic Republic of Vietnam's opium regime for the next decade. The regulations granted rights to poppy cultivation and opium production to growers in 'defined interzones', or areas of joint military-political administration, on two conditions. First, after each harvest, they paid a tax in kind levied at one-third of the manufactured latex (nhwa). Second, they sold the remaining two-thirds to State Shops (Mậu dịch). ${ }^{64}$ The agricultural tax on rice, likewise paid in kind at harvest, was the model for state claims on a share of

\footnotetext{
${ }^{63}$ Sarkissof, 'Objet: Opium', 8 March 1951, 2377/1oH/SHD.

${ }^{64}$ State Shops were administered by the Ministry of Industry and Commerce (Bô Công thuoong). Thủ tướng Chính phủ, 'Điều lệ tạm thời về thuốc phiện', 1951, File No. 3428, Bộ Nông Lâm (BNL) Record Group, NAVC 3 .
} 
smallholder production. An evolving system of official retail agents bought up the remainder.

On 5 March 1952, Vice Prime Minister Phạm Văn Đồng approved these core production, tax, and purchase principles to establish the Democratic Republic of Vietnam's 'temporary opium regime' (chế độ tạm thờ về thuốc phiện). Decision-150 recognized smallholding farmers as legal producers of opium, empowered Administrative and Resistance Committees to collect taxes, and registered State Shops as sole purchasing agents. The law also invoked police force to prohibit anyone other than these agencies from amassing or transporting 'already cooked opium latex'. ${ }^{65}$

In the interim between the $195^{1}$ Temporary Regulations and the March $195^{2}$ Decision, implementing agencies debated opium policy, explained its utility, and converged on a state monopoly. The Ministry of Finance's Central Tax Service offered three reasons why the government should allow highland cultivators to continue producing opium: first, an outright ban threatened their principle livelihood; second, opium functioned as a means of exchange for guerrilla fighters in French-occupied areas; third, it was necessary for morphine manufacture. ${ }^{66}$ The Agriculture Minister added that the trade's revenue filled state coffers but worried about declining production, observing that planted area in the Việt Bắc zone had decreased precipitously from $195^{\circ}$ to $195^{2}$. He argued for stabilizing cultivation at year $195^{\circ}$ levels in order to 'guarantee supply' and 'maintain monopoly purchase to fill the state budget'. ${ }^{67}$ The Agriculture Ministry's figures from September $195^{2}$ confirm opium's budgetary significance: the total purchase of 4.5 tons was valued at 5.823 billion Vietnamese Đồng (VNĐ), worth much more than all the tea in Vietnam (617 tons at $3.8 \mathrm{~b} \mathrm{VNĐ}$ ), its second most valuable crop. $^{68}$

Even as bureaucratic actors agreed on opium's benefits as source of morphine, guerrilla currency, and state revenue, they differed over handling the problem of addiction. The Tax Service opined that

\footnotetext{
${ }^{65}$ P. Văn Đồng, 'Nghị định số 15 o-TTg', 5 March 1952, 3428/BNL/NAVG 3 .

${ }^{66}$ Sở Thuê TW, 'Số _ _ /TC/ST/P 5 v/v Diêu lê tam-thoi vê thuoc phiên', $195^{1}$, 3428 /BNL/NAVG 3 .

${ }^{67}$ Bộ trưởng Bộ Canh Nông, 'Số $77 \mathrm{GN} / \mathrm{P}_{4}$ trích yêu: v/v điều lệ tạm thời về thuốc phiên', 12 February 1952, 3428/ BNL/NAVC 3.

${ }^{68}$ More precisely, the amount of tea purchased by State Shops and funnelled into the Democratic Republic of Vietnam budget. 'Tình hình thu mua lâm thổ sản trong 9 thánh đầu năm 1952', 1952, 5545/BNL/NAVG 3 .
} 
the government must 'grasp all manufactured opium' and 'hold a monopoly on its purchase' in order to eradicate addiction. ${ }^{69}$ For the Ministry of Labor, however, grasping a monopoly all the tighter let an old and vexing social problem slip through the government's fingers. The Labor Minister observed that 'growers in the mountains smoke opium like we smoke tobacco' and some 'mountain compatriots' had 'cruel' addictions dating back 20 or 30 years. Opium was not like other medicines, he warned, adding that any policy that did not account for grower usage would fail and, worse, risked causing a 'bad influence' among an ethnically divided and politically significant population. The Labor Minister argued for temporarily allowing growers to keep a small portion of their produce while offering leniency and support to wean them off their habits. ${ }^{70}$ Yet $1952^{2}$ 's Decision- 15 o made no such allowance, opting instead for a strict state monopoly aiming to tax and purchase all smallholder opium production.

In the Black River region, however, conditions on the ground dictated that Democratic Republic of Vietnam designs on opium worked differently in practice. Taxes were not yet on the agenda from $195^{1}$ to mid-1952 and, instead, State Shop cadres competed economically against merchants, markets, and routes backed by Thái Federation and French military. ${ }^{71}$ Democratic Republic of Vietnam trade operations reached from the region's eastern edge where Yên Bái Province served as a front to open guerrilla trade wars in occupied areas lying west towards Laos. Explicitly 'political' activities consisted of selling salt and cloth at low prices or giving them away to the poor. ${ }^{72}$ This 'economic struggle with the enemy' featured foremost the purchase of opium in occupied territory. Just after the opium harvest in April 1952, a mission behind the lines reported how the 'enemy' had taken advantage of Hmong deprivation by offering a 'crushingly' low price of five kilograms of rice for each tael of opium (lang, or $3^{8} \mathrm{~g}$ ). Yên Bái's provincial government subsequently issued marching orders to State Shop cadres and military escorts bearing rice, cloth, and salt

\footnotetext{
${ }^{69}$ Sở Thuê TW, 'Số /TC/ST/P5 v/v Diêu lê tam-thoi vê thuoc phiên', $195^{1}$, 3428 BNL/NAVG 3 .

${ }^{70}$ Nguyên Van Tao, Bộ trương Bộ Lao Đông, 'Số 63 LĐ/P1 trich yeu v/v Diêu lê tam-thoi vê thuốc phiên', 10 January 1952, 3428/BNL/NAVG 3 .

${ }^{71} \mathrm{~N}$. H. Thanh, 'Báo cáo tình hình công tác và sự thực hiện chương trình từ tháng $4.5^{1}$ đến hết tháng 7 năm $195^{1}$ của UBKCHC tỉnh Yên Bái', $3^{1}$ July $195^{1}$, 401/PTTg/NAVC 3 .

${ }^{72}$ N. H. Thanh, 'Báo cáo ba tháng thứ ba năm 1951', 28/x/1951, 401/PTTg/ NAVC 3 .
} 
to buy opium at its average 'market price' of 20 kilograms of rice per tael. Even if taxation was not yet part of the Democratic Republic of Vietnam opium regime, enforcing a monopoly on its exchange certainly was. By August 1952, the provincial government had bagged five cases of alleged 'smuggling' (buôn lậu). ${ }^{73}$

Aside from its role in the weapons trade, trading for opium at terms favourable to producers served underlying political and military objectives-what I call the revolutionary exchange. With each load of rice, cloth, and salt, State Shop cadres delivered a message regarding the significance of national unity and the government's 'nurturing care' for people in occupied areas. ${ }^{74}$ The sources do not indicate whether or not intended interlocutors actually believed the message; opium producers rarely, if ever, speak in French and Vietnamese archives. Nonetheless, abundant evidence demonstrates how Democratic Republic of Vietnam cadres used favourable terms of trade to propose alternative terms of rule. ${ }^{75}$ The programme followed a developmentalist logic, proposing to improve peasant conditions through state-managed exchange relations. A State Shop report on Sơn La and Lai Châu Provinces describes the 'over-riding goal' driving government purchase of 'local agroforestry products' (nông lâm thổsản), including opium:

Through the sale of local agro-forestry products, commerce and technology develop and the government's tax income grows. Through the peasantry's small contribution, together we can add new goods to win our economic struggle with the enemy and reduce commodity prices. People have more money, increase production, contribute a bit, buy goods cheaply, live easier lives-all bringing good political influence and increasing compatriot trust ... towards President Hồ and the Central Government. ${ }^{76}$

In their capacity as guerrilla traders-and, later, as tax assessorscadres performed explicitly political work by legitimizing the Democratic Republic of Vietnam's intertwined symbolic and material economies. Even as the Democratic Republic of Vietnam's monopoly

\footnotetext{
${ }^{73}$ N. Văn Hàm, 'Báo cáo mọi mặt công tác 6 tháng đầu năm $195^{2}$ của tỉnh Yên Bái', 20 August 1952, 455/PTTg/NAVC 3.

${ }^{74}$ S. Văn Minh, 'Báo cáo năm 1948 của UBKCHC Sơn-Lai', 15 January 1949, 78/PTTg/NAVC 3 .

${ }^{75}$ See captured Vietnamese-language documents translated into French for military intelligence, such as 'Thông trị: huy động dân công lính muối và chuyển hàng cho kế hoạch', 3o September 1953, 2699/1oH/SHD.

${ }^{76}$ P. N. Taan, 'Thu mua Nông, Lâm thồ sản', 17 May 1953, 5191/KTTTB/ NAVG 3 .
} 
ambition and State Shop institution echoed Indochina's and the Department of Customs and Excises', respectively, the Democratic Republic of Vietnam's attention to legitimacy departed from colonial precedent and remained a core task in Vietnam's post-colonial state. Between $195^{2}$ and 1954, however, securing legitimacy among diverse Black River peoples became increasingly fraught: largely Kinh-Viet cadres, soldiers, and officers exacted ever larger contributions from Hmong, Thái, Lao, and Khmu peasants—among other 'compatriots'and placed increasingly heavy burdens on the agrarian economy.

The People's Army's Northwest Campaign in late $195^{2}$ pushed the Thái Federation back into a corner of its former domain, marking a new period in the Democratic Republic of Vietnam opium regime. From October to December, the military advanced west from Yên Bái and secured most of Sơn La and southern parts of Lai Châu and Lào Cai, rendering as a 'newly liberated area' much of Vietnam's Black River region. Not coincidentally, they enlarged Democratic Republic of Vietnam territory and opened it for business. In August, prior to the campaign, the Vietnam Workers' Party Secretariat had instructed State Shops to follow close on soldiers' heels to exchange salt, cloth, and farm implements for 'local forest products' including cinnamon, benzoin, cardamom, and opium. ${ }^{77}$ Yên Bái Province's market town of Nghĩa Lộ housed a storage depot serving the expansion and intensification of materials used in the revolutionary exchange. ${ }^{78}$ Nestled in a valley surrounded by montane poppy fields, the town was an ideal site to observe and experiment with opium regulation. Long contested, Nghĩa Lộ's poppy fields and opium markets were now subject to Democratic Republic of Vietnam monopoly control.

In this context of military advance and anticipated returns on trade, a State Shop delegate in Nghĩa Lộ described the colonial opium economy and prescribed its national replacement. Written like a business plan or market prospectus, Nguyên Tan's secret report gives a rare glimpse into the Democratic Republic of Vietnam's self-conscious transformation of Indochina's opium regime. ${ }^{79}$ Nghĩa Lộ was home to

77 'Chỉ thị của Ban Bí thư ngày 16 tháng 8 năm 1952 thi hành chính sách dân tộc thiểu số ở Khu Q.T.', Văn Kiên Đảng Toàn Tập, vol. 13, $195^{2}$ (NXB Chính trị Quốc gia, Hà Nội, 2001), p. 254.

${ }^{78} \mathrm{~N}$. Khang, 'Báo cáo công tác vùng mới giải phóng trong 2 tháng 10, 11/52', 29 December 1952, 1 3o6/PTTg/NAVG 3 .

${ }^{79}$ N. Tan, 'Báo cáo công tác của phái viên tại tỉnh Yên Bái', 8 November 1952, $5^{187 / K T T T B / N A V G ~ 3 . ~ U n l e s s ~ i n d i c a t e d ~ o t h e r w i s e, ~ t h e ~ f o l l o w i n g ~ d i s c u s s i o n ~ d r a w s ~}$ on this document. 
some 6o licensed dens (each of which burned through seven kilograms of opium per month) and functioned as a trade hub linking Hanoi, Hai Phong, and Mong Cai to Hong Kong and Shanghai. ${ }^{80}$ Drawing on access to Indochinese capital, ethnic Kinh/Viet and Chinese 'big traders' worked with middlemen to purchase opium from Hmong growers and transport it by plane. Growers divided their harvest into four parts: one to consume, two to exchange for rice, and one more to trade for cloth, salt, kerosene, and silver. Over spring's harvest, opium's purchase price increased as its moisture content decreased: early on, during the lunar calendar's second month, middlemen circulated in villages to buy 'fresh' opium at 600 piastres per unit nén ( 1 nén $=10$ lạng $=375 \mathrm{~g}$ ) either in cash or towards payment of accumulated debt; in mid-season, middlemen sold to big traders drier product at 1,200 piastres per nén or, by season's end, at 1,800 piastres per nén. Over one season, therefore, curing raw opium from 'fresh' to 'latex' diminished its mass by just 20 per cent, while its market value leapt three-fold.

Even as he attended to the market's profitability, the delegate was sensitive to the problems of cultivator exploitation and addiction. Middlemen earned 'enormous profit', he alleged, by gaming rice quantity and quality in trades with 'poor' and 'hungry' Hmong growers. Worse, he continued, traders brought Thái rice-growers into this exchange to compound its profitability. After an initial barter of rice for opium, middlemen turned to Thái farmers for greater quantities of rice and then returned to hungry Hmong growers to advance the food at exorbitant interest rates. By collecting on loans at opium harvest for payment in kind, traders tripled their investment in a single year. In addition to losing at this uneven exchange, Hmong peoples suffered high rates of addiction, estimated at 4 o per cent of the local population. Each addict consumed, on average, 40 lạng ( 1.5 kilograms) annually.

For the State Shop delegate, grower exploitation and addiction indicated mismanagement of the opium trade, not a problem with opium per se. Exploitative trade caused low production, he charged, yet offered opportunities for growth under Democratic Republic of Vietnam leadership. Tellingly, he cross-referenced $195^{2}$ figures for annual production-6,ooo kilograms in Hà Giang, 500-6oo kilograms in Nghĩa Lộ, and 2,00o kilograms in Sơn La and Lai Châuwith 'production capacities'. Whereas Hà Giang produced more,

\footnotetext{
${ }^{80}$ Amosse, 'La culture de l'opium en 1948 dans la region de Nghia-Lo', 2 May 1948 , $2377 / 10 H / S H D$.
} 
he argued that the triumphant Northwest Campaign would soon double production in its liberated areas, to $5 \cdot 5^{-6}$ tons annually. The delegate explained: 'Given present political and military conditions', referencing the military's Northwest Campaign, and 'because of our financial-economic policy', referring to Decision-150, 'because Meo [Hmong peoples] are short of rice, and because the obstructed SonLai Road will really open up', he predicted that 'poppy planting would soon spread'. In other words, territorial advance promised high returns owing to state control over expanded commodity production and transport.

Of course, his prospectus hinged on whether or not beleaguered swidden cultivators would part with their dearest cash crop. Rather than orders, directives, and taxes, he advocated persuasion and explanation to elicit voluntary trade regulated by State Shops. But the revolutionary exchange did not function by ideas alone. In line with the secretariat's order, Nghĩa Lộ's depot now held ample supplies of salt, farm implements, tobacco, and clothing ready for cadres and itinerant traders to move west. It also held article Democratic Republic of Vietnam currency (VNĐ) and 7o kilograms of silver coinage (piastres), desired by Hmong for use in dress and cultural display. The delegate's report concluded with a map showing two sets of arrows: one branching out to north-western towns labelled 'salt, farm tools' and another converging back east on Yên Bái reading 'TF', shorthand for opium. ${ }^{81}$

In the months and years that followed the delegate's prospectus, state-led barter and purchase aimed to absorb all forms of highland material exchange, with force if necessary. In addition to brick-andmortar retail operations, State Shops supplied itinerant traders with commodities, monitored their prices, and endeavoured to replace the French piastre with the Vietnamese đồng. Shop agents encouraged traders to check their profit motive and, instead, to embrace an ethic of 'contribution' towards the national revolution and earn commendation for imparting a spirit of national unity. ${ }^{82}$ Nonetheless, French and Vietnamese observers alike identify exchange participants in ethnic terms - traders as Kinh or Chinese, swidden cultivators as Hmong, and wet-rice farmers as Thái-suggesting less a seamless nation than a plural society where peoples marked by ethnic difference and economic specialization met in the marketplace but rarely mingled

${ }^{81}$ Initials used 'f' to replace 'ph' in thuốc phiện.

${ }^{82}$ N. Khang, 'Báo cáo ba tháng đầu năm 1953', 15 April 1953, 47 1/PTTg/NAVC 3. 
outside it. ${ }^{83}$ Vietnamese reports are clear that anyone working outside approved channels fell under police jurisdiction. Just as the State Shop positioned itself at the centre of material exchange, the Zone's police enforced Democratic Republic of Vietnam monopolies on opium and currency. ${ }^{84}$ By monitoring boat traffic on the Red River, the police interdicted 'smuggling' activities oriented along the cross-border, upstream/downstream axis. ${ }^{85}$

As the 1953 opium season came to a close, the People's Army reaped a windfall abroad while the Democratic Republic of Vietnam's domestic harvest failed to meet expectations. After the Northwest Campaign, the People's Army in early 1953 ventured west beyond Vietnam's borders into neighbouring Laos. The military manoeuvre coincided with the Lao opium harvest, enabling the People's Army to take a substantial cut and leading a French official to grouse about losing the 'spoils of war'. ${ }^{86}$ Back home, a newly opened State Shop branch serving Sơn La and Lai Châu Provinces distributed 140 tons of salt, 70 tons of rice, 22,000 farm implements, and nearly 7,000 metres of cloth but collected just 78 kilograms of opium. Why was the opium yield so low? Disappointed officials blamed the delayed arrival of a cadre 'specialized in opium', presumably someone like Nguyên Tan, and a shortage of desirable trade goods, including cash and silver coinage ${ }^{87}$ Yet these explanations neglect worrisome conditions among growers.

In the First Indochina War, opium figured in a broader economy of politically driven scarcity. Large upstream flows of salt, rice, and clothing in early 1953 suggest new challenges facing cadres in

${ }^{83}$ Jerusalemy, 'Monographie'; 'Báo cáo công tác thuế nông nghiệp 1954 Khu Tây Bắc', 27 April 1955, 262 1/PTTg/NAVC 3. On the plural economy, see J. S. Furnivall, Colonial Policy and Practice: A Comparative Study of Burma and the Netherlands Indies, New York University Press, New York, $195^{6 .}$

${ }^{84}$ N. Khang, 'Báo cáo...' ', 15 April 1953, 47 1/PTTg/NAVC 3.

${ }^{85}$ Thu Bộ Công an, 'Kiểm soát trên sông để phóng biệt kích', 1 July 1953 , 2350/KTTTB/NAVC 3 .

${ }_{86}$ De Pereyra, 'Rapport Politique', 28 May 1953, 164/5oo/HCI/AOM. Although McCoy reports French purchase of this harvest (1991, p. 140), other scholars identify the People's Army as its principle beneficiary including C. Goscha, Vietnam or Indochina? Contesting Concepts of Space in Vietnamese Nationalism, NIAS, Copenhagen, 1995, p. 143; D. Feingold, 'Opium and politics in Laos', in Laos: War and Revolution, N. S. Adams and A. W. McCoy (eds), Harper and Row, New York, 197o, p. 336; J. Buttinger, Vietnam: A Dragon Embattled, vol. II, Praeger, New York, 1967, p. 792.

${ }^{87} \mathrm{~B}$. N. Tiêu, 'Báo cáo về tổ chức và hoạt động 3 tháng 4,5,6-53', 26 June 1953 , $5^{191 / K T T T B / N A V G ~ 3 ; ~ L . ~ V a ̆ n ~ M i ̀ n h, ~ ' B a ́ o ~ c a ́ o ~ t i ̀ n h ~ h i ̀ n h ~ K T T C ~} 6$ tháng đầu năm 1953', 4 July 1953, 2407/PTTg/NAVG 3. 
north-west Vietnam. Following the People's Army into rugged terrain, State Shop traders worked among populations suffering the effects of bitter, protracted war. Their role shifted, therefore, from guerrilla traders to managers of a shattered economy. Salt and farm tools were in desperately short supply, thousands of people were hungry in Sơn La and Yên Bái, and some areas reported starvation. ${ }^{88}$ While French colonial taxation, military procurement, and counterinsurgency had all contributed to difficult conditions, by late 1952, the People's Army of Vietnam too had begun to exert a lasting influence on the means and ends of agrarian production. Recruiting local workers (dân công) to build roads and ferry supplies for months at a time diverted precious labour from field, forest, and hearth. ${ }^{89}$ In a region where scarce labour limited agricultural production, leaving home and farm to work for state and military bore unintended but dire consequences. The year 1953 also commenced the region's agricultural tax on wet-rice, further reducing available food supplies. In sum, state resource claims and ongoing combat may have left people simply too busy, tired, hungry, and afraid to cultivate opium poppies.

As war dragged into 1954, moreover, hunger only worsened. While labour mobilization and agricultural taxes in 1953 elicited 'anxiety' (thắc mắc) and protest among Black River folk, state claims on local resources in 1954 intensified and expanded. 'The Committee taxes even grass, just taxes everything and snatches it all up,' said a resident of Kiến Thiết, Mộc Châu, 'so we left,' explaining why his village had abandoned a cassava field in mid-1953. Alleged 'bandits' undermined the revolutionary exchange with slogans like 'liberate yourselves from the agriculture tax' and 'free the dân công. ${ }^{90}$ Often dismissed in Democratic Republic of Vietnam reports as 'counterpropaganda', the slogans echo concrete concerns. During the Dien Bien Phu Campaign of late 1953 and into 1954, People's Army demands on local labour and food resources skyrocketed. ${ }^{91}$ Popular criticism increased correspondingly.

${ }^{88}$ C. C. Lentz, 'Mobilizing a frontier: Dien Bien Phu and the making of Vietnam', PhD thesis, Cornell University, 201 1, pp. 312-14.

${ }^{89} \mathrm{~K}$. MacLean, 'Manifest socialism: the labor of representation in the Democratic Republic of Vietnam', Journal of Vietnamese Studies, vol. 2, no. 1, 2007, pp. $27-79$.

90 'Tổng kết thuế nông nghiệp vùng mới giải phóng Tây Bắc', 1953, $5^{810 / K T T T B / N A V G} 3$.

${ }^{91}$ Lentz, 'Mobilization and state formation', p. 569 . 
Even while the battle raged in Dien Bien Phu and Democratic Republic of Vietnam cadres mobilized the region's population to serve the People's Army, State Shops still purchased the 1954 opium

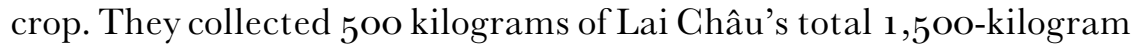
harvest and 1,266 kilograms of Sơn La's 2,60o kilograms, increasing their take substantially over the previous year. ${ }^{92}$ Vietnam's military triumph left a local population exhausted by war and subject to new claims on their agrarian resources. Yet national independence also emboldened cultivators, by now well versed in revolutionary socialist ideals, to demand greater rights to the opium they produced.

\section{Smouldering embers: opium contests transformed}

France's defeat at Dien Bien Phu and its withdrawal from northern Vietnam after the July 1954 Geneva Accords eliminated the Democratic Republic of Vietnam's principal competitor for monopoly control over opium's domestic purchase and tax. The Temporary Opium Regime (Decision-150 of March 1952) charged State Shops with purchasing two-thirds of smallholder production and empowered regional authorities with collecting the remainder as taxes, though they still had yet to do so. Expanding to borders with Laos and China, State Shops tracked the consolidation of Democratic Republic of Vietnam territory in the Black River region, which, as of May 1955, was administered as the Thái-Mèo Autonomous Zone in recognition of its two largest ethnic groups: Thái and Hmong (Mèo) peoples. Securing a monopoly on opium meant capturing cross-border trade and enacting Decision-150's tax provision on each grower's produce. The latter's onset in $195^{6}$ added to a rising tax burden, sparking deep unrest among highland smallholders, especially Hmong peoples, and raising questions about their rights and responsibilities in a Vietnamese nation-state.

In patterns reminiscent of the region's old caravan trade, lively commerce in the first year of national independence connected Vietnam's Black River opium growers with traders plying land and river routes. ${ }^{93}$ Along the Mã River, on a route criss-crossing the

${ }^{92}$ Ngô Thí Chúc và Nguyễn Thân, 'Báo cáo về tình hình...', 1 June 1955 , $5^{233 / K T T T B / N A V G ~} 3$.

${ }^{93}$ A. Forbes, "The "Cin-Ho" (Yunnanese Chinese) caravan trade with north Thailand during the late nineteenth and early twentieth centuries', Journal of Asian History, vol. 21, no. 1, 1987, pp. 1-47; E. R. Slack, Opium, State, and Society: China's 
southern frontier, Lao and Chinese merchants used packhorses to bring salt, textiles, tobacco, and clothing from Thanh Hoá, into Laos, and back into Vietnam. Another route from Luang Prabang followed the Ou River (Nam Ou) upstream and, after a ten-day journey, merchants reached Dien Bien with 'Franco-American' goods like flashlights, perfume, fragrant soaps, and pharmaceuticals (Cotab). Offering prices consistently cheaper than State Shops equipped traders with capital to buy and barter for opium, silver coins, and Indochinese piastres. Opium followed virtually every available route into and out of the region, spinning commercial webs reaching back and forth with Laos, into and out of China, and spilling into downstream Vietnam via Road 41 (present Quốc Lộ O) and the Black River. ${ }^{94}$ In Lào Cai, just south of China on the Red River, the opium trade steadily increased following war's end and French withdrawal. ${ }^{95}$ Private traders there out-bid State Shops in pursuit of 'local forest products' (lâm thổ sản)—notably cardamom and opiumand, grumbled officials, acted like they had even 'withdrawn from the purchase monopoly'. ${ }^{96}$

Now that independence granted the Democratic Republic of Vietnam sovereign territorial control, such continuities in trade faced significant changes in spatial regulation. After 1954, old trade routes crossing into Vietnam's borders entered a domain where the Democratic Republic of Vietnam had shifted from subverting a rival state's monopoly to enforcing its own. Private competition with State Shop retailers, deals in rival currencies, and loss of official opium purchases, therefore, prompted the Democratic Republic of Vietnam in early 1955 to shore up control of its domestic market in preparation for the season's harvest. Yet, like Indochina before, monopoly enforcement yielded mixed results. In March, the Thái-Mèo Zone limited crossings at the Lao-Viet border to social visits and restricted travellers to the frontier. Although official crossings decreased, principle trade routes still functioned: salt from Laos was available in the town of Sông Mã and police there had, by April,

Narco-Economy and the Guomindang, 1924-1937, University of Hawai'i Press, Honolulu, 2001, pp. 19-28.

${ }^{94}$ N. Thí Chúc và Nguyễn Thân, 'Báo cáo về tình hình...', 1 June 1955 , $5^{2} 33$ /KTTTB/NAVC 3 .

${ }^{95} \mathrm{~V}$. B. Tâns, 'Báo cáo 6 tháng đầu năm 1955 và chương trình hoạt động 6 tháng cuối năm 1955', 25 July 1955, 2379/KTTTB/NAVC 3 .

${ }^{96}$ Ban Kinh tế Tài Chính, 'Báo cáo kiểm điểm công tác kinh tế tài chính 7 tháng đầu năm', 22 September 1955, 2554/PTTg/NAVG 3 . 
busted four smuggling cases and netted a total of 70 kilograms of opium; Dien Bien Phu's market featured not only Cotab pills, but open transactions in undeclared opium. The Zone's police led 'guerrilla' operations to interdict the trade, including one mission abroad in Laos that busted three ethnic Chinese traders and captured 52 kilograms of opium. ${ }^{97}$ Never just 'foreigners', however, even Democratic Republic of Vietnam officials participated in underground trade: cadres and their families shipped product on the sly from Laos to downstream markets in Hòa Bình. 'Because gangs of strong smugglers stalked about,' explained a Zone policeman in mid-1955, 'State Shops purchased very insufficient amounts of opium, damaging economic and financial policy. ${ }^{9}$

When interdiction and border securitization measures failed to boost 1955's official purchase, central government officials took a decisive step towards enforcing claims directly on the next season's opium crop. When State Shops in the Thái-Mèo Zone netted only

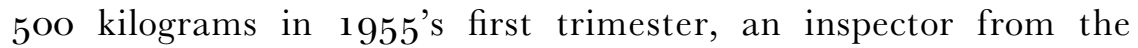
Ministry of Industry and Commerce expressed dismay and cast blame widely. He blamed the low net on poppy crop failures, the late arrival of trading teams in producing villages, and low purchase prices. Allowing local producers to keep a portion for household consumption also reduced the official cut. ${ }^{99}$ Yet it was the illicit trade that commanded attention from the inspector's superiors in Hanoi. In February 1956, a central government commission responded with measures to prevent 'smuggling mountain product downstream'. A Joint Tax and Customs Agency ordered relevant offices to strengthen anti-smuggling activities not just to punish monopoly violators and to increase State Shop purchases. More consequentially, such measures served to prepare the 'home front' for implementing a tax on the $195^{6}$ opium crop. ${ }^{100}$

The central government's 1956 decision to initiate an opium tax over-ruled protests by leaders of the Thái-Mèo Autonomous Zone, suggesting not only limits on the Zone's actual autonomy, but also

${ }^{97}$ N. Thí Chúc và Nguyễn Thân, 'Báo cáo về tình hình...', 1 June 1955 , $5^{2} 33$ /KTTTB/NAVG 3 .

${ }^{98}$ V. Boi Tâns, 'Báo cáo 6 tháng đầu năm 1955 ..', 25 July 1955 , 2379/KTTTB/NAVG 3 .

${ }_{99} \mathrm{~N}$. Thí Chúc và Nguyễn Thân, 'Báo cáo về tình hình...', 1 June 1955 , $5^{2} 33 /$ KTTTB/NAVG 3 .

${ }^{100}$ Giám đốc sở Hải quan TW and Giám đốc so thuế TW, 'Thông tư số 622/LSTVHQ: Liên sở thuế vụ và hải quan', 29 February 1956, 5246/KTTTB/NAVC 3. 
gaps in central leaders' understanding of regional social dynamics. In response to the central government's March letter of notification, the Zone's tax authority requested a holiday. Pointing to staff shortages and 'weak infrastructure' in the villages, they pleaded 'that the time was not right' to launch an opium tax. Nonetheless, the centre reiterated its position and explained that '[i]mplementing taxes guarantees fair contributions and benefits for unity' and, in addition, 'prevent[s] smuggling'. Although taxation actually increased smuggling in practice, the Zone's tax officials admitted that taxing opium did address two lingering sources of local tension. Following the Democratic Republic of Vietnam's successful military campaigns in $195^{2}$ and 1954, Thái peoples had begun to 'contribute' their agricultural tax on wet-rice but complained that Hmong opium crops were still exempt. Disparities in tax liability had created 'jealousy' between elevationally stratified and (agri)culturally differentiated social groups. In addition, Hmong wet-rice farmers paid up while Hmong opium farmers did not, leading to an 'unfair' situation. For central government leaders, the present arrangement violated core socialist values and policies, particularly ethnic unity within the Vietnamese nation and fairness regarding household contributions to the Democratic Republic of Vietnam state. ${ }^{101}$ In the end, the Zone's tax officials acknowledged the ideals of fairness and unity, grudgingly conceded the argument's merit, and reluctantly moved ahead with the tax.

True to local warnings, the centre's decision to tax opium expanded state claims on agrarian resources and risked sources of Democratic Republic of Vietnam legitimacy embraced during the revolutionary struggle. The opium tax fell disproportionately on Hmong growers disaffected with ratcheting state claims, earlier on their labour, now on their opium, and soon on their swidden food crops. During the 195354 Dien Bien Phu Campaign, the Democratic Republic of Vietnam had required Hmong peoples to perform dân công labour service, effectively reversing French colonial policy exempting them from corvée. ${ }^{102}$ Suffering after coming down from the cooler heights and enduring hard labour in valley heat, many Hmong men and women fell ill and

101 'Báo cáo tổng kết công tác thuế thuốc phiện năm 1956 (đã được thông qua trong hội nghị tổng kết thuế NN tháng 1/57 của Khu)', 14 January 1957 , $5^{869 / K T T T B / N A V G ~} 3$.

${ }^{102}$ L. Văn Mười, 'Báo cáo 3 tháng 4,5,6 năm 1949 của UBKCHC Liên tỉnh Sơn-Lai', 1949, $187 / \mathrm{PTTg} / \mathrm{NAVG}_{3}$. 
some even died of exhaustion and related disease. ${ }^{103}$ Expectations of post-colonial improvement failed to materialize in 1955 when, for the third year in a row, hunger spread through the Zone, affecting 20,000 people; starvation and related disease took 5 o lives. ${ }^{104}$ In Mường Nhè, chronic food shortage left one village with no children under the age of five. ${ }^{105}$ Increasing taxation amidst stagnating social conditions compromised faith in development and belied official promises to 'care for the people'.

To add insult to injury, the $195^{6}$ opium tax caught growers by surprise, appeared to violate promises, and augured more taxes to come. Two Hmong growers in Co-May Commune stopped a cadre in his tracks and recalled a pact forged in war. 'During the time of secrecy,' they said, 'cadres told us that anyone whose child in the army was sacrificed [hy sinh, that is, killed] would receive a Government forbearance [chiêu cố].' And, now, reported the cadre, they 'demanded their forbearance'. Cadres responded to such demands by comparing the Democratic Republic of Vietnam agenda favourably with French Indochina's, explaining how tax revenue now enabled broader access to food, salt, and clothing. Perhaps tired of these explanations, however, some cultivators greeted cadres with outright ridicule. In Chiềng Công Commune, one man scoffed:

Cadres and army officers want to take and do so without my knowing-just pay us with your opium or we'll take your land and do as we please, just give it to the Government, a government no different from the French. ${ }^{106}$

In addition to equating colonial with post-colonial rule, this extraordinary statement points to a real dilemma. Taxation did in fact have a reciprocal relationship with material well-being: after colonial domination and two devastating wars, the Democratic Republic of Vietnam was interested in development but desperately short of resources. If cadres failed to persuade people that revenue collection was a necessity, they risked state legitimacy by inviting comparisons with the same colonial exploitation they had taught cultivators to denounce.

${ }^{103}$ Lentz, 'Mobilizing a frontier', p. 307.

${ }^{104}$ Sở Công an Khu, 'Báo cáo tồng kết công tác năm 1955 của Công an Khu tự trị Thái-Mèo', 13 October 1955, 2379/KTTTB/NAVC 3.

${ }^{105}$ Phòng TAHC, Giám đôc sở Công an KTT, 'Báo cáo tình hình 6 tháng đầu năm 1955', 1 July 1955, 2379/KTTTB/NAVC 3.

${ }^{106}$ UBHC Khu TTTM, 'Báo cáo tổng kết...', 14 January 1957 , $5^{869 / K T T T B / N A V G} 3$. 
Popular anxieties about Democratic Republic of Vietnam tax and labour policy expanded with intensifying claims on food crops grown alongside opium. The agricultural tax, already in place on wet-rice, expanded on an experimental basis in $195^{6}$ to include swidden rice and corn in Mường Lay District, former seat of the Thái Federation. Once again, ending a tax holiday caught local growers by surprise, fanning widespread concerns that the agricultural tax would come to include swidden farmers throughout the Zone. It did so in $1957 \cdot{ }^{107}$

\section{Early post-colonial contradictions}

Disaffection among opium growers contributed to an ongoing Democratic Republic of Vietnam legitimacy crisis centred on Vietnam's Thái-Mèo Autonomous Zone. A political movement offered a vision of a just king who would appear in response to expressions of popular devotion such as fasting, animal sacrifice, dance, and prayer. Once the supernatural sovereign appeared on Earth, prophecies told how he would vanquish enemies and deliver followers from their present miseries, especially taxes and labour service, into wealth, bounty, and happiness. Followers quit work, abandoned their fields, staged protests, built hideouts deep in the forest, and offered cutting critiques of the post-colonial social order. Democratic Republic of Vietnam officials attributed causes of the movement, referred to as 'calling for a king' (xung đón vua) in Vietnamese-language historical sources, to foreign meddling by Franco-American imperialists. ${ }^{108}$ Although the explanation is plausible given recent and ongoing counterinsurgency operations, they nonetheless overlooked evidence of their own government's complicity.

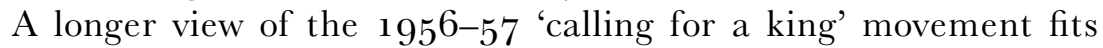
with a millenarian tradition among highland peoples of mainland South East Asia and, in particular, suggests historic parallels with the

${ }^{107}$ Chủ tịch, UBHC Mường Lay, 'Báo cáo tháng $10-195^{6}$ từ $20 / 9$ đến $20 / 10 / 5^{6}$ ',

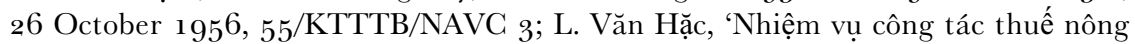
nghiệp 57', 31 July 1957, 5941/KTTTB/ NAVG 3 .

${ }^{108}$ In addition to primary sources cited below, secondary sources include Công an Tỉnh Lai Châu, Lịch sủ Công an Nhân dân (1952-1975), Công an Nhân dân, Hanoi, 1994; P. Văn Lực (chủ biên), Một số Vấn đề về Lịch sử và Văn hoá Tây Bắc, NXB Đại học Sư phạm, Hanoi, 2011. 
1918-21 Pa Chai uprising. ${ }^{109}$ Though the former never amounted to an armed rebellion, both social movements appealed to Hmong peoples, featured messianic activities, and aired popular grievances, especially Thái domination and opium taxation. Like French administrators before them, Kinh-Viet officials were relatively unfamiliar with the region's complex social landscape and worked with hereditary Thái elites to manage local affairs. Unlike the earlier movement, Khmu and Dao peoples, among other 'small ethnicities', joined forces with their more numerous Hmong neighbours. They articulated a critique of Democratic Republic of Vietnam regional administration-one that hitched downstream Kinh/Viet political cadres to upstream Thái powerbrokers. ${ }^{110}$ For the king's callers, the Thái-Mèo Zone recalled old patterns of Thái domination dating from the pre-colonial Sip Song Chau Thai to the neocolonial Thái Federation. Seen from this angle, the Zone's $195^{6}$ decision to tax opium represented only the latest in a series of powerful efforts to wrest from cultivators their most valuable cash crop.

By embracing an idea of self-rule and carrying it beyond regional autonomy, movement supporters cast doubt on Vietnam's national unity and revealed splits within the Democratic Republic of Vietnam state itself. 'Autonomy,' snorted one man in Văn Chấn, 'only when there are no more Kinh people will there be real autonomy.' 111 Not only was the nation riven with ethnic tensions, but the Democratic Republic of Vietnam state itself was far from monolithic, as opium taxation showed. In August 1956, tax education provided two highranking officials - a member of the Zone's People's Assembly and the Vice Chairman of Mai Sơn's People's Committee-with opportunity to greet large audiences, spread word about a king's imminent arrival, and mobilize more supporters. ${ }^{112}$ Informed by revolutionary ideals and steeped in guerrilla warfare, participants in the

${ }^{109}$ Scott, The Art of Not Being Governed, Chapter 8; I. Baird, 'Millenarian movements in southern Laos and North Eastern Siam (Thailand) at the turn of the twentieth century: reconsidering the involvement of the Champassak Royal House', South East Asia Research, vol. 21 , no. 2, June 2013, pp. 257-79.

${ }^{110}$ Sở Công an Khu TTTM, 'Báo cáo tổng kết kiểm điểm tình hình và công tác từ 1/56 đến 1o/56', 18 October 1956, 2389/KTTTB/NAVG 3; C. Trọng, Ngườ Thái ờ Tây Bắc Việt Nam, NXB Khoa học Xã hội, Hanoi, 1978.

${ }^{111}$ Phòng TAHC, Giám đốc sở Công an KTT, 'Báo cáo...', 1 July 1955 , 2379/KTTTB/NAVC 3 .

${ }^{12}$ Sở Công an KTTTM, 'Báo cáo về tình hình "Vua Xá và Vua Mèo" Trong Khu', 16 February 1957, 2414/KTTTB/NAVG 3 . 
calling-for-a-king movement animated their own understanding of autonomy and produced new collective forms.

Calling-for-a-king activities coalesced around a critique of tax and labour policies, escalating until a turn of events in 1957 prompted a military and police crackdown. Although official reports downplay taxation and compulsory labour service as sources of discontent, they still demonstrate that smallholders interpreted such claims as real grievances. At the movement's peak, an investigation in highland communities above Dien Bien Phu found villagers who had abandoned their opium fields, slaughtered their livestock, and let rice plants go to seed. Among them were people who 'mocked and complained about labor service and opium policies' and others who 'held forth publicly that now [tax collectors] take our opium, tomorrow swidden rice, and perhaps even all pigs and chickens too'. ${ }^{113}$ While anti-productionism and critiques of tax policy earned official disapproval, it was not until the movement took a violent turn that the Democratic Republic of Vietnam forced an end. When people in Sông Mã and Mai Sơn used slogans like 'Strike the Thái and take their wet-rice fields, strike the Kinh and spread freedom', they presented a discomfiting mirror to a regime founded on socialist revolutionary principles, born through violence, and nearly paralysed by land reform downstream. After an incident in Quan Hoá District, Thanh Hoá Province in April 1957 and a deadly military confrontation with protesting villagers in Mộc Châu County (present-day Sơn La Province) in May, the police, military, and courts coordinated efforts to jail leaders and end the movement. ${ }^{114}$

The Democratic Republic of Vietnam's political crisis in the TháiMèo Zone shaped and reflected the region's official opium receipts (see Table 1). In 1956, the first year of opium taxation, 12 of the Zone's 17 counties were taxed at a rate of 25 per cent, or one-quarter of their declared harvest, while the remaining five earned an exemption based on their 'unstable politics'. Some 6,718 households yielded a total harvest of 2.4 tons $\left(64,111\right.$ lạg) for a tax take of 568 kilograms. ${ }^{115} \mathrm{In}$ 1957, when xung vua activities reached a crescendo, the Zone reduced

${ }^{113}$ Nguyễn Thuân, UBHC Châu Dien Bien, 'Báo cáo tổng kết công tác tuyên truyền chống âm mưu xưng vua của địch ở xã Độc Lập’, 12 September 1957 , 2413/KTTTB/NAVG 3 .

114 “Chỉ thị số 36 CT/TW v/v giải quyết vấn đề "xưng vua đón vua" và các vấn đề tương tư ở miền nuí', 10 July 1957, 2413/KTTTB/NAVC 3.

115 'Báo cáo tổng kết công tác thuế thuốc phiện năm 1956', 14 January 1957 , $5^{869 / K T T T B / N A V G ~} 3$. 
TABLE 1

Official opium receipts for Northwest Vietnam, 1953-1960.

\begin{tabular}{|c|c|c|c|c|c|c|c|c|}
\hline Year & 1953 & 1954 & 1955 & $195^{6^{*}}$ & $1957^{\wedge}$ & $195^{8}$ & 1959 & 1960 \\
\hline Area & Sơn I & $\begin{array}{l}\text { and La } \\
\text { Province }\end{array}$ & Châu & & nái-Mèo & Autono & lous Zor & \\
\hline $\begin{array}{l}\text { Harvest } \\
\quad \text { (kilograms) }\end{array}$ & - & 4,100 & - & $2,43^{6}$ & $1,14^{2}$ & 5,369 & - & - \\
\hline $\begin{array}{l}\text { Tax } \\
\quad \text { (kilograms) }\end{array}$ & NA & & & $5^{68}$ & 283 & 1,354 & 620 & 753 \\
\hline $\begin{array}{l}\text { Purchase } \\
\text { (kilograms) }\end{array}$ & 78 & 1,766 & $5^{\mathrm{OO}}$ & - & $3^{85}$ & 3,555 & 1,262 & 793 \\
\hline
\end{tabular}

Source: NAVG 3 .

* Twelve of 17 counties (châu) reporting. ^ Eight of 17 districts reporting.

the rate to 20 per cent and expanded the taxable area to all districts. ${ }^{116}$ Yet, 1957's reported harvest of 1.14 tons (30,078 lang) counted only eight districts and netted a paltry 283 kilograms (7,520 lạg) in taxes, prompting the Zone to forecast an additional 1.5 tons (40,ooo lạng) of production from non-reporting areas. Yet the 1957 forecast was wildly optimistic given widespread political unrest, false declarations, and smuggling. Summing up the mood in light of past experience with taxes, one grower vowed 'We won't get fooled again'. ${ }^{117}$

Reflecting on 1957's dismal tax record and noting a relationship between rising addiction and increasing contraband, the Zone's leaders ordered new measures for $195^{8}$ and netted a bumper crop. Just before the harvest, deputy director of the Thái-Mèo Autonomous Zone and native son of Dien Bien Phu, Lò Văn Hặc, issued Order19 Managing Mountain Region Product. The order bumped the tax rate back up to 25 per cent, launched a political campaign on a euphemized commodity, and prescribed constant cultivated area. ${ }^{118}$ Moreover, growers could now keep 7 per cent of their harvest, while a new revenue-sharing agreement incentivized local tax collection, entitling the Thái-Mèo Zone to 20 per cent of the Ministry of Finance's

116 'Báo cáo công tác thuế nông nghiệp năm 1957', 9 August 1957, 5941/KTTTB/NAVG 3 .

${ }_{117}$ Or, 'dân năm nay không dại nhu năm ngoài nũa'; Lâm Liên, UBHC KTTTM, 'Báo cáo v/v thu thuế sản phẩm miền núi 1957’, 23 May 1957, 5953/KTTTB/NAVC 3 .

${ }^{118}$ L. Văn Hặc, 'Chỉ thị số $19 / K T$ “Công tác quản lý SFMN năm 1958 "', 22 February $195^{8,} 5993 /$ KTTTB/NAVG 3 . 
1, ooo-kilogram target and half of any overage. ${ }^{119}$ Something in the mix worked. The year $195^{8}$ turned out a record crop: the reported harvest reached $5 \cdot 4$ tons (141,295 lạng), tax receipts increased to 1.4 tons (valued at $178 \mathrm{~m}$ VNĐ), State Shop purchases rose to 3.5 tons, and a balance stayed with cultivators. ${ }^{120}$ In all, the official harvest surpassed the Ministry of Agriculture's reported purchase of 4.5 tons for the Việt Bắc Zone in 1952. It also exceeded colonial estimates for the Northwest Region and matched State Shop delegate Nguyên Tan's savvy 1952 regional forecast.

1958's haul threw tensions embedded in the Democratic Republic of Vietnam's opium regime into sharp relief. The high yield earned accolades from the prime minister's office in Hanoi: 'The state has grasped six-fold in revenue over year 1957 and achieved the highest numbers since the Central Government implemented a monopoly on the purchase of special product. ${ }^{, 121}$ Once again, however, figures did not account for opium that leaked into highly organized contraband networks. Ringleaders employed buyers to scour villages as well as cadres and soldiers to transport small loads (one to two kilograms) to Hanoi and Hải Phòng for collection and distribution. ${ }^{122}$ Further, coercion crept back into relations between growers and state monopolists. In the heights above Dien Bien Phu, soldiers joined farmers in their fields ostensibly to 'help with the harvest' and 'add a sense of trust among the people'. ${ }^{123}$ Yet the show of force in the wake of the xung vua movement was unmistakable. Poppy growers there expressed 'hatred' for the cadre ranks. Even more pointedly, they wondered why a government (Chinh phü) would preach opium's

\footnotetext{
${ }^{119}$ Sở Tài chính và sở Thương nghiệp, 'Biên bản thành toàn thuế sản phẩm đặc biệt', 22 November 1958, 3228/KTTTB/NAVC 3.

${ }^{120}$ Sở Thương nghiệp, 'Báo cáo tổng kết công tác thu mua và thu thuế sản phẩm miền núi 1959', ${ }_{5} 5$ December 1959, 6058/KTTTB/NAVC 3; N. Hanh, 'Báo cáo kiểm điểm công tác thuế sản phẩm miền núi năm 1959’, 5 September 1959, 6059/KTTB/NAVC 3 .

${ }^{121}$ Bùi Công Trung, T/L Thủ tướng phủ, 'Thủ tướng phủ số 3484 -TN v/v lãnh đạo trồng SFĐB năm 1959', 4 September 1958, 5326/BNL/NAVC 3.

${ }^{122}$ L. Văn Hặc, 'Công tác quản lý SFMN năm 1958', 22 February 1958, 5993/KTTTM/NAVG 3 ; L. Văn Hặc, 'Thông tư số 152/NG Sử lý các vụ vận chuyển và buôn bán thuốc phiện trái phép', 16 July 1958, 5978/KTTTB/NAVC 3 .

${ }^{123}$ UBHC Châu Dien Bien, 'Báo cáo tông kết thuế nương 5 xã Mèo khu vực VinhQuang năm 58', 13 June 1959, 5987/KTTTB/NAVC 3 .
} 
evils yet ply its trade. 'What is the Government doing, speaking of opium's harm but compelling its sale?' asked one cultivator. ${ }^{124}$

The opium cultivator pointed to a contradiction between Democratic Republic of Vietnam rhetoric and practice. In his September 1945 Declaration of Independence, Hồ Chí Minh had cited colonial opium and alcohol monopolies as evidence of how France had abused 'Liberty, Equality, and Fraternity' by weakening 'our race' with addiction and impoverishing the peasantry with taxes. ${ }^{125}$ Since then, Democratic Republic of Vietnam cadres working in north-west Vietnam discouraged opium use but encouraged its cultivation, sale, and tax. The desultory conditions of Dien Bien's growers in $195^{8-}$ addicted, poor, and coerced-echoed those under French colonialism. As such, the cultivator's critique reveals the limits of an official line articulated in the $195^{2}$ State Shop prospectus. Where did the problem with opium regulation lie? In alleged French mismanagement? Or with state-managed opium regimes more broadly? The problem that confronted the Democratic Republic of Vietnam, I suggest, was located in contradictions between sources of post-colonial legitimacy premised on improvement, fairness, and unity, and a source of state revenue whose extraction had been and remained harmful, uneven, and divisive.

By the late $195^{\circ}$, the Democratic Republic of Vietnam faced new international challenges as well as older difficulties regulating opium markets. As the Democratic Republic of Vietnam prepared for war against the southern Republic and the Lao Government of National Unity split into warring factions, opium retained value among parties vying for its trade and the power it brought them. In a late1959 report on opium purchase and tax, the Thái-Mèo Autonomous Zone's Commerce Agency observed that 'Mountain product is a kind of commodity related to problems of economy, politics, and society'. ${ }^{126}$ By referencing a Marxist idea of the commodity as a form of congealed social relations, the statement acknowledges how opium's socialist commodification combined relations of exchange and

124 'Chính phủ nói thuốc phiện có hại thì thu mua caủ dân làm gì'. Ban Sản phẩm miền núi Châu Dien Bien, 'Báo cáo tổng kết tình hình sản phẩm miền núi của 5 xã Mèo và 4 xã Thái', 12 June 1958, 5994/KTTTB/NAVC 3.

${ }^{125}$ Hồ Chi Minh Toàn tập, vol. 4, 1945-1946, NXB Sự thật, Hanoi, 2ooo, p. 1; H. C. Minh, Selected Writings, I920-1969, The Gioi Publishers, Hanoi, 1994, p. 53.

${ }^{966}$ Sở Thương nghiệp, KTTTM, 'Báo cáo tổng kết công tác thu mua và thu thuế sản phẩm miền núi 1959', 15 December 1959,6058/KTTTB/ NAVG 3 . 
rule. Although the statement confirms the revolutionary exchange's ongoing significance, it nonetheless denies how trading opium to fund anti-colonial warfare had generated an unstable mixture of official and unofficial economies. In fact, early Democratic Republic of Vietnam opium markets evinced a direct relationship between the size of state claims and the growth of contraband trade. The onset of opium taxation in 1956 increased unlawful exchange, invigorating old transnational trade routes and ensnaring new officials in smuggling networks. After popular criticism in 1957, the central government reduced its cut in $195^{8}$, increasing overall compliance with lawful sales. The amount of illicit commerce, therefore, suggests a meter of popular consent regarding licit terms of exchange.

Contests over opium and its exchange did not begin with the Democratic Republic of Vietnam, nor did they end with the bumper crop of 1958. Like the Indochinese monopoly it followed, the Democratic Republic of Vietnam monopoly was and remained an aspiration as well as a work in progress. Between the first and second Indochina Wars, who benefited from opium's exchange value animated a politics characterized by negotiation and compromise as well as an oscillation between state tactics of legitimation and coercion. The crackdown on the xung vua movement indicates how a renewed militarization of production and exchange relations steadily reduced spaces for negotiation and subjected cultivators to coercion. Nonetheless, by 1960, as the Democratic Republic of Vietnam moved back into war footing, its opium regime still had yet to fulfil its $195^{2}$ mandate: falling short of monopoly control, adjusting tax rates to local demands, and allowing smallholders to keep a portion of their produce. ${ }^{127}$ Smallholder initiative and extralegal competition checked state power to claim resources that cultivators and traders considered rightfully their own property. Cultivating subjects earned these small victories through everyday politics that built on knowledge, tactics, and values learned from the same tax agents, cadres, and soldiers with or against whom they learned and struggled, negotiated and compromised.

${ }^{127}$ Sở Hải quan TW, 'Nghị quyết v/v kiểm soát chống buôn lậu sản phẩm miền núi năm 1960', 1960, 615o/KTTTB/NAVG 3; Sở Tài chính KTTTM, 'Báo cáo v/v tiến hành công tác thuế nông nghiệp từ sau Hội nghị tổng kết của Khu đến nay', 18 May $1960,615^{1 / K T T T B / N A V C ~} 3$. 


\section{Conclusion}

For French Indochina and the Democratic Republic of Vietnam alike, opium was a dangerous yet lucrative commodity. After the Second World War, when France attempted to re-conquer its Indochinese domain, the opium trade yielded funds for friend as well as foe, stoking contests that reached deep into the post-colonial era. In lean years after the First Indochina War, opium retained its value for an independent Vietnam: growers earned cash, the treasury collected revenue, and hospitals obtained morphine. Yet, by capitalizing on an addictive substance and governing through revolutionary socialism, the Democratic Republic of Vietnam's opium regime contained a contradiction recognized by cultivators in the Black River region. Just as opium's use carried a whiff of colonial degeneracy, regulating its production and exchange bore Indochina's legacy of ethnicized violence, complicating post-colonial projects of national unity and socialist development.

Not simply a source of highland smallholder independence, opium attracted state interests to South East Asia's historically autonomous hinterlands. Before the Golden Triangle emerged as a global narcotics producer in the 1960 s, opium contests in the neighbouring Black River region already intersected with a politics of autonomy at three spatial scales. First, enacting an unpopular opium regime in the post-colony reinvigorated old contraband networks crossing new international borders of Vietnam, Laos, and China. Transnational smuggling linked South East Asian cultivators to faraway markets when relations of narcotics production and consumption were in the process of globalizing. Second, the regime temporarily weakened Democratic Republic of Vietnam ambitions to centralize decisionmaking and economic planning in its vast Thái-Mèo Autonomous Zone. Opium production in their backyards empowered local officials when negotiating with superiors in distant Hanoi.

At the third and smallest scale, cultivators drew on ideas of reciprocity and fairness embedded in the revolutionary exchange to negotiate property rights. Just as the Democratic Republic of Vietnam equated compulsory labour service with citizenship, so too did its taxation of rice and opium stand for egalitarian relations of exchange and improved access to socially necessary goods. Educating people in socialist values produced subjects versed in a liberatory language who, not surprisingly, had ideas of their own. Cultivators used concepts of justice, equality, and participatory democracy to challenge state 
claims on agrarian resources and demand greater control over the means of subsistence.

Contests over opium and the social forms they produced built on long-standing yet highly mutable social cleavages. The colonial project of divide and rule cast fluid identities in rigid categories associated with political privilege, economic specialization, and violence. Postcolonial attempts to universalize citizenship duties ran up against ethnicized political blocs who contested state material claims on scarce resources and national symbolic claims on primary identity. Like French Indochina before, Democratic Republic of Vietnam efforts to monopolize opium shaped ethnic difference anew and in unpredictable ways. Thái wet-rice farmers accused Hmong opium growers of unfair tax advantages. Yet Thái elites occupied privileged positions in the Thái-Mèo Zone, raising old suspicions of unjust domination among a pan-ethnic coalition of swidden cultivators and opium growers. When Hmong, Dao, and Khmu peoples struggled over the means and ends of agrarian production, they also sought to define and secure their own spaces for community reproduction. Their calls for a just kingdom levied a trenchant critique at paired ethnic majoritiesThái in the zone and Kinh/Viet in the nation-underlying the newly configured Democratic Republic of Vietnam state. As cultivating subjects produced in relation to state power, opium growers recognized the tense social relations built into the post-colonial nation-state and experienced its capacity to coerce and cajole compliance.

Seen in a comparative and regional perspective, decolonization in Vietnam carried elements of an old state yet introduced new forms of popular legitimacy limiting its power to dominate. When cultivators equated French and Vietnamese rule, they pointed out institutionally similar opium regimes and structural continuities in state finance. In this respect, Vietnam was similar to revolutionary Indonesia and China, where opium revenue likewise financed republican governments and armies. ${ }^{28}$ Yet, unlike in China and Indonesia, opium continued beyond war's end in Vietnam to supply state revenue and drive politics in sites of production. Armed with a radical political consciousness, however, post-colonial cultivators negotiated

${ }^{128}$ R. Cribb, 'Opium and the Indonesian revolution', Modern Asian Studies, vol. 22, no. 4, 1988, pp. 701-22; Chen Yung-fa, 'The blooming poppy under the red sun: the Yan'an Way and the opium trade', in New Perspectives on the Chinese Communist Revolution, T. Saich and H. van de Ven (eds), M.E. Sharpe, New York, 1995, pp. 263-98. I thank Melissa Macauley for the latter reference. 
state claims and defended property rights. Indeed, Democratic Republic of Vietnam rhetoric was more than just words. Principles of fairness, equality, and improvement were based on old French revolutionary ideals denied to, yet enacted by, colonial subjects. ${ }^{129}$ Vietnam's national state extended these ideas in the guise of revolutionary socialism: its promise of radical equality, mass political participation, and economic development did persuade many to follow. But citizenship duties struck many as unfair, ensuring that coercion still lurked in the post-colony. Sometimes, force leapt to the fore with trade interdictions, protest shootings, and outright warfare.

Carrying an old opium regime into a new era was difficult even for officials, imparting legacies that continue to trouble state actors and vex scholars using national archives. Operating an opium regime in the post-colony raised moral questions for officials who, as a result, covered their documentary tracks. Echoing the practice of China's Communist Party, Democratic Republic of Vietnam officials euphemized opium with vague, innocuous terms like 'local agroforestry product'. ${ }^{130}$ Such euphemization indicates ethical qualms among socialist humanists dealing in a harmful substance and nationalists distancing themselves from a colonial vice. Officials also used secrecy to hide their actions. When ministers and other political elites debated opium as such (that is, thuốc phiện), they left documents stamped 'secret', restricting documentary access down to the present day.

Burying opium in the archives, however, hides a longer story continuing beyond the scope of this article. 'Cultivating Subjects' ends in 1960 when escalating confrontation between the Democratic Republic of Vietnam and the southern Republic of Vietnam changed the politics of opium anew yet, with American intervention, followed old colonial patterns. During the Second Indochina War, United States of America covert warfare applied French tactics by using profits from the opium trade to arm anti-communist Hmong militias in Laos. United States of America actions contributed to the Golden Triangle's rise and advanced a counterinsurgency tactic later deployed in Afghanistan against the Soviet Union. ${ }^{131}$ In post-war

${ }^{129}$ See L. DuBois, 'An enslaved Enlightenment: rethinking the intellectual history of the French Atlantic', Social History, vol. 31, no. 1, 2006, pp. 1-14.

130 'Special product' (techan) in 1940 S Chinese Communist Party documents. Chen Yung-fa, 'The blooming poppy', p. 273.

${ }^{131}$ McCoy, The Politics of Heroin, especially Chapter 7 and pp. $445^{-} 5^{2}$. 
Vietnam, legal opium production ceased in the early 1990s, yet opiate addiction and smuggling remain vexing problems. ${ }^{132}$ Moreover, the politics of resource control and ethnicity remain contentious in Vietnam's Black River region, where cultivating subjects still negotiate with the nation-state and challenge its post-colonial domination. ${ }^{133}$

${ }^{132}$ N. Văn Dự, 'Về tình trạng nghiện hút thuốc phiện ở vùng đồng bào các dân tộc tỉnh Lai Châu', Dân tộc học, no. 77, 1993, pp. 12, 55-8.

${ }^{133}$ See N. Dao, 'Damming rivers in Vietnam: a lesson learned in the Tây Bắc region', Journal of Vietnamese Studies, vol. 6, no. 2, 201 1, pp. 106-40; T. T. T. Ngo, 'Protestant conversion and social conflict: the case of the Hmong in contemporary Vietnam', Journal of Southeast Asian Studies, vol. 46, no. 2, 2015 , pp. 274-92. 